ISSN 1045-6333

\title{
A NEW APPROACH TO VALUING SECURED CLAIMS IN BANKRUPTCY
}

Lucian Arye Bebchuk Jesse M. Fried

Discussion Paper No. 321

$04 / 2001$

Harvard Law School Cambridge, MA 02138

The Center for Law, Economics, and Business is supported by a grant from the John M. Olin Foundation.

This paper can be downloaded without charge from:

The Harvard John M. Olin Discussion Paper Series: http://www.law.harvard.edu/programs/olin_center/ 


\title{
A New Approach to Valuing Secured Claimsin Bankruptcy
}

\author{
Lucian AryeBebchuk* and Jesse M. Fried**
}

\begin{abstract}
$\underline{\text { Abstract }}$
In many business bankruptcies in which the firm is to be preserved as a going concern, one of the most difficult and important problems is that of valuing the assets that serve as collateral for secured creditors. Valuing a secured creditor's collateral is needed to determine the amount of the creditor's secured claim, which in turn affects the payout that must be made to the creditor. Such valuation has generally been believed to require either litigation or bargaining among the parties, which in turn give rise to uncertainty, delay, and deviations from parties' entitlements. This paper puts forward a new approach to valuing collateral that involves neither bargaining nor litigation. Under this approach, a marketbased mechanism would determine the value of collateral in such a way that no participant in the bankruptcy would havea basis for complaining that secured creditors are either over- or under-compensated. Our approach would considerably improve the performance of business bankruptcy and could constitute an important element of any proposal for bankruptcy reform.

JEL classification: G33, K22

Keywords: bankruptcy, secured debt, collateral , bankruptcy reform (c) Lucian Bebchuk and Jesse Fried

* William J. Friedman and Alicia Townsend Friedman Professor of Law, Economics, and Finance, Harvard Law School; Research Associate, National Bureau of Economic Research and Center for Economic Policy Research (bebchuk@law.harvard.edu).

** Acting Professor of Law, Boalt Hall School of Law, U.C. Berkeley (friedj@aw.berkeley.edu). We thank Daniel Dockery, Andrew Guzman, John Landers, Lynn LoPucki, Bob Rasmussen, Mark Roe, Steve Schwarcz, David Skeel, SteveSugarman, GeorgeTriantis, Fred Tung, Elizabeth Warren and participants in seminars at Boalt $\mathrm{Hall}$ and Vanderbilt for their helpful comments. Valuable research assistance was provided by Elena Kouvabina, MikeLysobey, Ben Shreck, and, especially, Simran Bindra. For financial support, Lucian Bebchuk is grateful to the John M. Olin Center for Law, Economics, and Business at H arvard Law School, and Jesse Fried is grateful to the U.C. Berkel ey Committee on Research and the Boalt Hall Fund. Future revisions of this paper may be retrieved from www.harvard.edu/ faculty/ bebchuk.
\end{abstract}




\section{Table of Contents}

$\begin{array}{ll}\text { I. INTRODUCTION } & 1\end{array}$

II. The Valuation 6

$\begin{array}{ll}\text { A. Secured Creditors' Rights O utside A nd Inside Bankruptcy } & 7 \\ \text { 1. Rights O utside Bankruptcy } & 7\end{array}$

2. Rights Inside Bankruptcy 8

a. The A utomatic Stay 8

b. The Secured Creditor's Rights at the End of the the Proceeding 10

B. The Problem with V aluing Collateral 11

1. The $\mathrm{N}$ ecessity of $\mathrm{V}$ aluing Collateral 11

2. The A bsence of a $V$ erifiable Figure 12

3. Comparison to the Problem of $V$ aluing the $D$ ebtor as a Whole

4. The Separate Problem of D elay 16

C. Existing $M$ ethods of $V$ aluing Collateral 16

1. The U se of Litigation and Bargaining 17

2. The Shortcomings of Litigation and Bargaining 19

D. The Valuation Problem Under M arket-Based R eforms 21

1. The A uctions A pproach 22

2. The 0 ptions A pproach 23

3. TheV aluation Problem as I mpediment to $M$ arket-Based Reforms

25

III. The Proposed A pproach 25

A. Reconceptualizing the Secured Creditor's Claim 26

B. The M echanism and its Three Stages 27

C. First Stage: The A uction of the $\mathrm{N}$ on recourse $\mathrm{N}$ ote 30

1. The Conduct of the A uction 30

2. The Value of the A uction ed $\mathrm{N}$ ote 31

3. Bidding by the Secured Creditor 34

4. W ould any Participant $\mathrm{H}$ avea Basis for Complaining? 35

a. Complaining that the price is too $\mathrm{H}$ igh 36

b. Complaining that the price is too Low 36

c. Liquidity Constraints 37

D. Second Stage: Completion of the Bankruptcy Proceeding 40 
E. Third Stage: Post-Bankruptcy Resolution of the N on recourse N ote

1. Resolution of the $\mathrm{N}$ ote

a. Collateral $\mathrm{H}$ as $\mathrm{G}$ oing Concern V alue for D ebtor

b. Collateral D oes not $\mathrm{H}$ ave $\mathrm{G}$ oing Concern $\mathrm{V}$ alue for D ebtor

2. Post-Bankruptcy Liquidity Problems

F. Incorporating the M echanism into Bargaining-Based or O ptions-Based Bankruptcy

45

1. Bargaining-Based Bankruptcy

46

2. O ptions-Based Bankruptcy

G. An Alternative V ersion of The M echanism

48

$H$. U sing the M echanism to Implement Partial Priority

52

IV.CONCLUSION

54 


\section{INTRODUCTION}

In any business bankruptcy in which the firm is to becontinued as a going concern, one of the most difficult problems is valuing the individual assets that serve as collateral for the firm's secured creditors. Valuing a secured creditor's collateral is important because the value of the collateral determines theamount of the creditor's secured claim-- and therefore the amount paid to the creditor at the end of the proceeding. Such valuation has thus far been believed to require either litigation or bargaining among the bankruptcy participants. However, litigation and bargaining, the methods by which collateral is valued today, give rise to uncertainty, deviations from parties' bankruptcy entitlements, and additional transaction costs. This paper puts forward a new market-based approach to valuing collateral that does not require litigation or bargaining during the proceeding. The proposed mechanism would determine secured claims in such a way that no one could have a basis for complaining that secured creditors are either over- or undercompensated. This mechanism could considerably improve the performance of Chapter 11 as well as any other business bankruptcy system, including the various market-based systems that have been put forward as alternatives to Chapter 11.

Creditors frequently take security interests in their borrowers' assets. ${ }^{1}$ If a borrower files for bankruptcy, one of the more important tasks in the ensuing proceeding is valuing the assets that serve as collateral for the borrower's secured loans. ${ }^{2}$ Identifying the collateral's

1 Theavailable data suggest that a substantial amount of U.S. business debt is secured. See, e.g., John D. Leeth \& Jonathan A. Scott, The Incidence of Secured D ebt: Evidence from the Small Business Community, $24 \mathrm{~J}$. FIN. \& QUANTITATIVE A NALYSIS 379, 379 (1989) (reporting that a 1982 Interagency Task Force on Small Business Finance study found that al most $80 \%$ of the dollar volume of large- and smallbusiness loans was secured and that a $1983 \mathrm{~N}$ ational Federation of Independent Business study found that $78 \%$ of the total volume of small-business Ioans was secured). As of January 2001, commercial banks held $\$ 1,652,300,000,000$ in loans secured by real estate. See Real Estate Loans at All Commercial Banks Seasonally Adjusted, Federal Reserve Board of Governors, H.8 Release, available at http:/ / www.stls.frb.org/ fred/ data/ loans/ realln.

2 See, e.g., RAYMOND T. NIMMER \& JAMESJ. WhITE, CASESAND M ATERIALSON BANKRUPTCY 171 (3rd ed. 1996) (noting that valuation of assets in Chapter 11 will be "critical"); Charles D. Booth, The Cramdown on Secured Creditors: A n Impetus Toward Settlement, 60AM. BANKR. L.J. 69, 101 (1986) (noting that valuation of collateral is "one of the most important" issues in Chapter 11); Darrell G. Waas, Letting the Lender Have It: Satisfaction of Secured Claims By A bandoning a Portion of the Collateral, 62 AM. BANKR. L.J. 97, 106 (1988) (same). 
value is essential because bankruptcy law gives a secured creditor a "secured claim" equal to the value of its collateral, up to the amount owed, 3 which must be paid in full. 4 The creditor also has an "unsecured claim" for any deficiency, for which the creditor will typically receive much less than 100 cents on the dollar. ${ }^{5}$ Thus, the higher the value of the collateral, the higher the payout to the secured creditor at the end of the proceeding. 6 And because higher payouts to secured creditors mean lower payouts for unsecured creditors, the valuation of collateral is important not only for secured creditors but also for unsecured creditors.

Outside of bankruptcy, or when the borrower's assets are sold piecemeal in bankruptcy, the value of each asset serving as collateral can be objectively and verifiably determined by auctioning the assets individually. ${ }^{7}$ However, in a bankruptcy where the business is reorganized or sold as a going concern to a third party, ${ }^{8}$ there is no auction of individual assets that can be used to determine their value. A nother method is needed to value assets that serve as collateral for secured creditors.

Currently, the value of collateral is determined either through litigation or bargaining in the shadow of possible litigation.9 Using

3 See 11 U.S.C. § 506 (1994).

4 See infra Part II.A.2.b.

5 In the United States, payouts for unsecured claims in business bankruptcies are, on average, less than 50 cents on the dollar. SeeLynn M. LoPucki \& WilliamC. Whitford, Bargaining over Equity's Share in the Bankruptcy Reorganization of Large, Publicly H eld Companies, 139 U. PA. L. Rev. 125, 142 tbl. 3 (1990) (finding that the average payout promised -- but not necessarily paid -- to holders of general unsecured claims in 43 reorganization cases filed after October 1, 1979 and confirmed by March 31, 1988 was about 32 cents per dollar and that even in successful Chapter 11 reorganizations of large, publicly traded corporations with relatively little secured debt, the average payout to holders of general unsecured claims is less than 50 cents on the dollar).

6 See DAVID G. EPSTEIN et.al., BANKRUPTCY §§ 10-23 to -27 (1993).

7 See Douglas G. Baird, The Hidden Virtues of Chapter 11:An Overview of the Law and Economics of Financially Distressed Firms, Chicago Working paper in Law and Economics 6 (1997).

8 In bankruptcies of publicly traded firms, approximately $78 \%$ of debtors emerge as going concerns. Se LYNN M. L OPUCKI \& SARA D. K ALIN, THEFAILUREOF Public Company BanKRUPTCIES IN Delaware and NEW York: EmpIRICAL EVIDENCE OF A 'RACE TO THE BOTTOM' 8 (working paper, 2000).

9 SeeEPSTEIN et.al, supra note 6 , at $\S \S 10-1$ to -7 . Therearetwo types of assets whose value can bedetermined without litigation or extensive bargaining. Thefirst type consists of publicly traded securities and commodities. Publicly traded assets have an easily ascertainable and undisputable market value. The second type consists of assets whose highest plausiblevalueis so small that it is not worth the 
litigation and bargaining to value the debtor's assets may lead to deviations from the parties' bankruptcy entitlements either in favor of or against the secured creditor.10 Litigation and bargaining areal so likely to increase the length of the bankruptcy proceeding and its attendant costs, including both direct bankruptcy costs and the indirect costs associated with a business being in bankruptcy. ${ }^{11}$

The problem of valuing collateral arises in a business bankruptcy whenever the debtor firm is sold as a going concern, either in Chapter 7or in Chapter 11, as well as whenever the firm is reorganized under Chapter 11.12 This problem would also arise under the two market-based approaches that have been put forward as alternatives to Chapter 11: the auctions approach, 13 and the options approach. ${ }^{14}$ In fact, the problem of valuing collateral has been regarded as a major obstacle to their effectiveness. 15

parties' timeto bargain over their value. The parties should beableto quickly reach an agreement about thevalue of thesetwo types of assets. Thefocus of this paper is on assets whose values cannot easily and indisputably be established by their trading prices in a public market and whose plausiblevalues arehigh enough that the parties will bewilling to invest resources litigating and bargaining over them.

10 See id. at § 3-27 (b).

11 See infra Part II.D.2.

12 See Elizabeth Warren, Fed. Judicial Ctr., Business Bankruptcy, 140-41 (1993).

13 The auctions approach was put forward in Douglas G. Baird, TheU neasy Casefor Corporate Reorganizations, 15J. L EGAL STUD. 127, 128 (1986), and THOMASH. JACKSON, THE LOGIC AND LIMITSOF BANKRUPTCY LAW 221-24 (1986). It followed an earlier proposal by Mark Roeto auction $10 \%$ of a reorganized company's securities. See Mark J. Roe, Bankruptcy and D ebt: A N ew M odel for Corporate Reorganization, 83 Colum. L. REv. 527 (1983). Theauctions approach was subsequently advocated in Michael C. Jensen, Corporate Control and the Politics of Finance, 4J. A PPLIED CORP. FIN. 31-32 (1991). The auctions approach is discussed in more detail infra Part II.E.

14 The options approach was put forward in Lucian A. Bebchuk, A N ew A pproach to Corporate Reorganizations, $101 \mathrm{HARV}$. L. REV. 775 (1988) [hereinafter Bebchuk, O ptions A pproach]. This approach was subsequently endorsed and adopted as the basis for bankruptcy reform in P. Aghion et.al., The Economics of Bankruptcy Reform, 8 J.L. ECON. \& ORG. 523 (1992) and Oliver HART, FIRMS, CONTRACTS, AND FINANCIAL STRUCTURE, 156-57, 169-85 (1995). For a recent account of the options approach, see Lucian A. Bebchuk, $U$ sing 0 ptions to $D$ ivide $V$ aluein Corporate Bankruptcy, 44 EUROPEAN ECON. ReV. 829 (2000) [hereinafter Bebchuk, U sing 0 ptions]. Theoptions approach is discussed in more detail infraPartll.E. For a comparison of the options and auctions approaches, see Lucian A. Bebchuk, Chapter 11, in The NeW PALgRaVe Dictionary OF ECONOMICSAND THE LAW, (Vol. 1 1998), at 219-224 [hereinafter Bebchuk, Chapter 11].

15 See Mark Roe, Corporate Reorganization and Bankruptcy: Legal and FINANCIAL MATERIALS 602 (2000). 
In this paper, we offer a market-based solution to the problem of valuing collateral. The proposal is based on a new way of thinking about a secured creditor's claim. As is well known, a secured creditor's claim can be broken into two components: (i) the part that is fully secured (or the "secured claim") -- which is the lesser of the amount owed and the value of the collateral, and (ii) the unsecured part (or the "unsecured claim") -- the part of the claim, if any, that is not secured, which is simply the excess of the amount owed over (i). The insight underlying our proposal is that the value of component (i) can bethought of as equivalent to the value of a nonrecourse loan16 that (a) has a face amount equal to the secured creditor's claim and (b) is backed by the secured creditor's collateral. Thus, the problem of breaking the claim into a fully secured claim and an unsecured claim translates into the problem of valuing such a nonrecourse loan.

We show how such a nonrecourse loan can be valued before the end of the bankruptcy proceeding in a way that would not disrupt the proceeding, reduce the going concern value of the firm's assets, or give any party a basis for complaining about being under-compensated. Under our proposal, there would be an auction of a nonrecourse note with a face amount equal to the secured creditor's claim, backed by the asset serving as the creditor's collateral. The winner of the auction -- the "noteholder" -- would havetheright to collect the faceamount of the note from the debtor immediately after the bankruptcy proceeding terminates but with recourse only to the collateral. When the proceeding ends, the noteholder should be able to use the note to obtain from the debtor the collateral, up to the amount of the note. The auction of the nonrecourse note would occur immediately before the end of the bankruptcy proceeding.

Since the nonrecourse note would be resolved shortly after the auction, bidders should be willing to buy the note for the value of the collateral, up to the amount of the secured creditor's claim. The price the note fetches at the auction would thus determine the amount of the creditor's secured claim. The proceeds of the auction would be used to pay that claim in full. The excess of the creditor's claim over the auction price would constitute the unsecured claim of the creditor and be pooled with other unsecured claims.

Wewould like to emphasize that our proposal does not involvethe secured creditor or any other party foreclosing on collateral during the

16 A nonrecourse loan is a secured loan under which thelender's remedies in the event of a default are limited to seizing and selling the collateral. For a more detailed description of nonrecourse loans, see infra Part III.A. 
course of the bankruptcy proceeding. Werethereto be such a foreclosure, the debtor might not have the cash necessary to participate in the subsequent auction of the collateral. Thus, the problem with foreclosure during the proceeding is that the going concern value of the asset, if any, could be destroyed. ${ }^{17}$ The proposed mechanism avoids this problem by postponing the possibility of foreclosure until after the end of the bankruptcy proceeding, when the debtor is solvent. At that time, the debtor should have the financial ability and incentive to retain any collateral that has going concern value.

We show how the mechanism we put forward would -- in addition to preserving the going concern value of assets -- facilitate the valuation of collateral in a way that does not involve costly and time-consuming litigation and bargaining. And we demonstrate how the procedure could be designed to ensure that secured creditors are neither over- nor undercompensated. We then show that the procedure could be combined both with the existing Chapter 11 regime as well as with the two market-based reform proposals that have been put forward as alternatives to Chapter 11.

Wealso offer for consideration an alternative, "auctionless" version of our mechanism that can be employed whenever the firm is sold for cash at the end of the proceeding. As under the first version of the procedure, the secured claim would be converted into a nonrecoursenote due immediately after the end of the bankruptcy proceeding. However, the note would not be auctioned. Instead, the secured creditor would keep the note and enforce it immediately after the end of the bankruptcy proceeding. To the extent that the resolution of the note leaves the secured creditor with a deficiency claim, that claim would need to be paid after the bankruptcy proceeding -- at the same rate as similar unsecured claims were paid at the end of the proceeding. We offer two methods for ensuring that such deficiency claims would indeed receive the same treatment as other unsecured claims in the bankruptcy proceeding.

Finally, the paper considers the possibility of using our mechanism to implement partial priority. As was noted earlier, bankruptcy law currently entitles secured creditors to be paid in full for their secured claim, which is the value of the collateral, up to the amount owed. However, as we have emphasized in prior work, the case for providing secured claims with full priority is not compelling, and there are reasons to consider as alternatives partial priority regimes under which secured

17 See infra Part II.A.2.a. 
creditors are entitled to less than full priority in their collateral. ${ }^{18}$ We show that our mechanism could be modified to provide secured creditors with their entitlements under partial priority rules just as easily as it could provide secured creditors with their entitlements under full priority.

Our paper is part of, and builds on, the literature on market-based approaches to bankruptcy. In the past two decades, bankruptcy scholars seeking alternatives to the bargaining approach of Chapter 11 have put forward market mechanisms based on the use of auctions or options.19 Our work is very much in the spirit of this larger project. However, as we noted earlier, researchers working on market-based mechanisms have thus far not been able to develop a market-based mechanism for valuing secured claims. They haveabstracted from this issue, assuming implicitly or explicitly that the value of the collateral in bankruptcies will be either known or will be determined, as it is now, by bargaining and litigation. The contribution of our work is to providea market-based mechanism for dealing with this essential element of bankruptcy proceedings. In doing so we build on ideas from both the auction and options approaches.20

The analysis is organized as follows. Part II describes the fundamental challenge posed by the need to value collateral in going concern bankruptcies. It also discusses the inescapable shortcomings of the existing methods of valuation, litigation and bargaining. Part III puts forward our approach to valuing assets serving as collateral. Part IV concludes.

\section{The Valuation Problem}

This Part examines the problem of valuing collateral in business bankruptcy. Section A describes the basic rights of a secured creditor in and out of bankruptcy. Section B explains the necessity of valuing collateral, and then discusses the fundamental problem with valuing

18 See Lucian Arye B ebchuk \& Jesse M. Fried, TheU neasy Casefor the Priority of Secured Claims in Bankruptcy, 105Y ALE L.J. 857, 862 (1996) [hereinafter, Bebchuk \& Fried, U neasy Case]; Lucian A rye Bebchuk \& Jesse M. Fried, TheU neasy Casefor the Priority of Secured Claims in Bankruptcy: Further Thoughts and a R eply to Critics, 82 CORNELL L. R EV . 1279 (1997) [hereinafter Bebchuk \& Fried, Reply to Critics]; JesseM. Fried, Taking the Costs of Priority Seriously, 51 Q. REP. 328 (1997).

19 See infra Part II.D.

20 A s will be made clear by the analysis offered infra Part III, theauctioning of the nonrecourseloan under our procedure is in the spirit of the auctions approach and our attempt to ensure that nobody could have a basis for complaining about the outcome -- by giving participants a number of ways to directly and indirectly participate in the auction -- is in the spirit of the options approach. 
collateral in any bankruptcy in which the assets are worth moreas a going concern -- the lack of an indisputable, verifiable value for the collateral. Section C briefly considers how collateral is currently valued in Chapter 11 -- through litigation and bargaining -- and describes the deficiencies of these methods. Section D shows that the problem of valuing collateral arises not only in Chapter 11 reorganizations, but al so in connection with the two market-based mechanisms -- options and auctions -- that have been offered as alternatives to Chapter 11.

\section{A. The Secured Creditor's Rights O utside and Inside Bankruptcy}

\section{Rights 0 utside Bankruptcy}

Outside bankruptcy, under state debtor-creditor law, a secured creditor whose borrower (the "debtor") has defaulted may seize the collateral, sell it at auction, and keep the proceeds of the sale up to the amount owed. ${ }^{21}$ If the proceeds exceed the amount owed, the creditor must return the excess to the debtor. ${ }^{22}$ If the proceeds fall short of the amount owed, the secured creditor may attempt to collect the deficiency from the debtor using the remedies available to unsecured creditors. 23

For ease of exposition, we will introduce here theterm "foreclosure value." We define the "foreclosure value" as the proceeds of selling the asset at an auction. Thus, outside bankruptcy, the secured creditor is entitled to the foreclosure value of the collateral, up to the amount owed, and is an unsecured creditor for any deficiency. ${ }^{24}$

For example, suppose that Creditor extends a \$100 loan to Debtor. The loan is secured; a machine serves as the collateral. Debtor later defaults on the loan. Creditor may seize the machine and sell it at

21 See generally LaWrence P. King \& Michael L. CoOK, CReditors' Rights, DEBTORS PROTECTION AND BANKRUPTCY §§ 3.01--3.14 (1997); U.C.C. §§ 9-601 to 628. To the extent the secured creditor incurs transaction costs in repossessing and selling the collateral, the creditor generally may use proceeds of the auction to pay theseexpenses beforeapplying theremainder of the proceeds to reducetheamount ow ed. See, e.g, U.C.C. § 9-615(a). By “proceeds," wemean the proceed s of the sale net of thesetransaction costs. For ease of exposition we will ignorethesetransaction costs and assume that the net proceeds of the sal e equal the sal eprice Adding such costs would not affect any of our conclusions.

22 See James J. White $\&$ Robert S. SUMmers, Uniform COMmercial Code (4th ed. 1995) § 25-10 (1995) (pp. 919-920).

23 Id. If theloan werenonrecourse, the secured creditor would haveno right to collect the deficiency. Unless wespecify otherwise, all of theloans described in this paper are recourse loans.

24 Id. 
auction. The sale price is $\$ X$. Creditor may keep the machine's foreclosure value -- the sale proceeds of the auction, $\$ X$, up to $\$ 100$, the amount owed. If $\$ X$ is less than $\$ 100$, Debtor is still obligated to pay Creditor the difference, $\$ 100-\$ X$. Creditor can thus sue Debtor (as an unsecured creditor) for this deficiency.

\section{Rights Inside Bankruptcy}

One of the most important consequences of a bankruptcy filing is the automatic stay. 25 The automatic stay, described in more detail below, generally prohibits creditors from initiating or continuing collection efforts against the debtor.26 Thus, when a defaulting borrower files for bankruptcy, the automatic stay usually prevents a secured creditor from seizing the collateral, selling it, and keeping the proceeds. ${ }^{27}$

However, bankruptcy law accepts as a basic principle that the secured creditor has the right to receive the value of its collateral (up to the amount owed).28 Thus, at the end of the bankruptcy proceeding, the creditor is paid in full for that amount.29 The creditor also receives an unsecured claim for any deficiency, which is almost never paid in full. 30 Before considering in more detail secured creditors' entitlements at the end of the bankruptcy proceeding, however, it is important to consider first the aim and operation of the automatic stay.

\section{a. The A utomatic Stay}

When a debtor files for bankruptcy, the automatic stay stops all collection activities against the debtor. ${ }^{31}$ Thus, unlikeoutsidebankruptcy,

25 See EPSTEIN et. al., supra note 6, at § 3-1.

26 See 11 U.S.C. § 362 (1994). Seegenerally EPSTEIN et. al., supra note6, at §§ 3-1 to -7.

27 See 11 U.S.C. 362(a) (1994); Douglas G. BAIRd \& THOMAS H. JACKSON, Cases, Problems, and Materials on Security Interests in Personal Property 481 (2nd ed. 1987).

28 See Bebchuk \& Fried, U neasy Case, supra note 18, at 862 . Secured claimsare treated similarly in other bankruptcy regimes. For a discussion of the treatment of secured claims in other bankruptcy systems, see INTERNATIONAL CORPORATE INSOLVENCY LAW (Dennis Campbell ed., 1992) (surveying insolvency laws of various countries).

29 See infra Part II.A.2.b.

30 See Bebchuk \& Fried, U neasy Case, supra note 18, at 862.

31 See COLLIER ON BANKRUPTCY $\S 362.01$ (2000); EPSTEIN et. al., supra note 6, at $\S$ 3-6. 
the secured creditor may not seize the collateral and sell it at auction. ${ }^{32}$ $\mathrm{N}$ or may the secured creditor pursue the debtor as an unsecured creditor for any part of its claim. 33

The economic goal of the automatic stay is to protect assets that have "going concern value." For purposes of this paper, assets have going concern value for a particular firm if they are worth more to that firm as part of a going concern than they would be worth if sold piecemeal. ${ }^{34}$ If there were no automatic stay, the debtor's secured creditors might seize these assets, dismembering the debtor and destroying the assets' going concern value. 35 The assets would be sold for less than their going concern value, and participants in the bankruptcy would get less than if the assets remained with the debtor.

An asset that has going concern value for the debtor would, by definition, be worth more to the debtor than any other bidder at auction. As a result, if the secured creditor were to seize the collateral, we might expect the debtor to be the highest bidder for the asset at auction, or to prevent the auction al together by paying the creditor what it expects to get from the debtor at auction. Thus, the automatic stay might seem unnecessary for preserving the asset's going concern value.

However, the debtor is likely to be cash-constrained for much of the bankruptcy proceeding. If a secured creditor could seize its collateral, the debtor might not be able to compete in an auction or to prevent the auction even when it values the asset more than any other party. As a

32 Thereare two exceptions to theautomatic stay. First, the stay may belifted if (1) the debtor has no equity in the collateral and (2) the collateral is not necessary for the reorganization of the debtor as a going concern. See 11 U.S.C. §§ 361, 362 (1994). Second, the stay may be lifted if the secured creditor's interest in the debtor's property is not "adequately protected." See 11U.S.C. §§ 361-364(1994). A secured creditor's interest in the collateral is considered adequately protected if the debtor compensates the secured creditor (with cash or additional collateral) for any decrease in theamount of its secured claim resulting from a declinein the value of the creditor's original collateral. See EPSTEIN et. al., supra note6, at 146. Weassume throughout that thesecured creditor is adequately protected and that thecollateral is necessary for the reorganization of the debtor. Therefore, neither of these exceptions to the automatic stay applies and the collateral remains with the debtor during the course of the bankruptcy proceeding.

33 See COLLIER ON BANKRUPTCY § 362.01 (2000).

34 When the assets are sold piecemeal at an auction they are purchased and used by another going concern. Thus an asset is considered to havegoing concern valueas part of Firm A if and only if the asset is worth more to Firm A than it is to any other firm that might purchase the asset at an auction.

35 MARK S. SCARBERRY et. al., BusinesS REORGANIZATION IN BANKRUPTCY: CASESAND MATERIALS 119-23 (1996). 
result, the going concern value of the collateral might belost if therewere no automatic stay.

\section{b. The Secured Creditor's Rights at the End of the Proceeding}

The automatic stay deprives the secured creditor of its right to seize and sell the collateral during the bankruptcy proceeding. ${ }^{36}$ However, bankruptcy law attempts to preservetheother most important right of the secured creditor: priority in the collateral. It is a fundamental principle of bankruptcy law that a secured creditor has a right to receive the value of its collateral, up to the amount owed. ${ }^{37}$ The principle is implemented by giving the secured creditor a "secured claim" equal to the value of the collateral, up to the amount owed, which must be paid in full at the end of the proceeding. 38

In addition, the secured creditor is given the rights of an unsecured creditor in bankruptcy to the extent that the value of the asset falls short of the amount owed. 39 Thus, the law gives the creditor an "unsecured claim" for any deficiency. 40 Unsecured claims are generally not paid in full and are often paid only a small fraction of their face value.

As was explained in Part II.A.1, outside bankruptcy the secured creditor has a right to the "forecl osure value" of the collateral (defined as the proceeds of the sale of the asset at auction), up to the amount owed, and an unsecured claim for any deficiency. We will assume throughout that bankruptcy law intends to give a secured creditor that same entitlement. That is, a creditor has the right to the "forecl osure value" of the collateral - the price it w ould fetch at auction, up to theamount owed, as well as an unsecured claim for any deficiency. It is worth noting here that as a descriptive matter bankruptcy entitlements tend to reflect nonbankruptcy entitlements. ${ }^{41}$ There is also an important line of

36 See Collier ON BANKRUPTCY $\S 362.01$ (2000).

37 See Bebchuk \& Fried, U neasy Case, supra note 18, at 862. Wequestion in other work whether secured creditors should have full priority in their collateral. Seid; Bebchuk \& Fried, Reply to Critics, supra note 18; Fried, supra note18. However, for present purposes we take the principle of full priority as given. As Part III.H. explains, the procedure we put forward can beused to implement not only full priority but also a rule of partial priority.

38 11U.S.C. $\S 506$ (1994). The secured claim may be paid in full with cash or with a note whose value is at least the amount of the secured claim.

39 See COLLIER ON BANKRUPTCY § 501 (2000).

4011 U.S.C. § 506 (1994); W ARREN, supra note 12, at 59-60.

41 See Thomas Jackson, Bankruptcy, N on-Bankruptcy Entitlements, And The Creditors' Bargain, 91 Y ALE L.J. 857, 859 (1985). As a matter of positivelaw, it is not entirely clear what a secured creditor is entitled to get on account of their secured 
bankruptcy scholarship arguing that as a normative matter creditors' bankruptcy entitlements should mirror as closely as possible their nonbankruptcy entitlements. 42

Returning to our example, in bankruptcy Creditor would have a secured claim for the foreclosure value of the machine, $\$ X$, up to the amount owed, $\$ 100$. Creditor thus would have a secured claim for the lesser of $\$ X$ and $\$ 100$. This claim would be paid in full. If $\$ X$ is less than $\$ 100$, Creditor would be considered an unsecured creditor for the deficiency, $\$ 100-\$ X$, and be given an unsecured claim of $\$ 100-\$ X .43$

\section{B. The Problem with V aluing Collateral}

1. The $\mathrm{N}$ ecessity of $\mathrm{V}$ aluing Collateral

One of the most important functions of the bankruptcy proceeding is to distribute to participants the value of the bankruptcy pie-- the value of the debtor's assets -- according to the amount of each participant's claim and its priority ranking. ${ }^{44}$ The bankruptcy proceeding cannot be completed until each participant receives at least the minimum that it is entitled to under the applicable distribution rules.

As was explained in section A, a secured creditor is entitled to the value of its collateral, up to the amount owed, and has a claim for any deficiency. In Chapter 11, this rule is implemented by the "fair and

claim. The U.S. Supreme Court recently decided that in appraising assets the standard is the "replacement value" of the asset. SeeAssociates Commercial Corp. v. Rash, 117S. Ct. 1879(1997). However, theSupremeCourt has not provided clear guidance to lower courts as to how "replacement value" should bedetermined. Se Jean Brauchner, Getting it for $Y$ ou W holesale: M aking Sense of Bankruptcy $V$ aluation of Collateral After Rash, 102 Dick. L. ReV. 763 (1998). As a result, there is still considerableambiguity about how collateral should bevalued in bankruptcy. Se Gary Klein, 0 pinion Raises M ore Q uestions than it A nswers, 16 AM. BANKR. INST. J 18 (1997); Edie Walters, A n A mbigu ous A nswer: The Effect of A ssociates Commercial Corporation v. Rash on Chapter 11 and Chapter 13 Collateral V aluations, 35 Hous. L. REV. 953 (1998); Kenneth Reich, Continuing the Litigation of Collateral V aluation in Bankruptcy: A ssociates Commercial Corp. v. Rash, 26PEPP. L. Rev. 655(1999); Chris Lenhart, Toward a M idpoint V aluation Standard in Cram D own: O intment for the Rash D ecision, 83 CORNELL L. REV. 1822 (1998).

42 See BAIRD, supra note 13; JACKSON, su pra note 13, at 20-33; Douglas G. Baird, Bankruptcy's U ncontested A xioms, 108 Y ALE L.J. 573 (1998).

43 If $\$ X$ exceeds $\$ 100, C$ would al so have the right to be paid in full for post petition interest and certain costs incurred in connection with theloan. Sœ11U.S.C. $\S 506$ (b). For ease of exposition, we will assumethroughout that $\S 506(b)$ does not apply. This assumption does not affect any of the analysis.

44 See JACKSON, supra note 13, at 
equitable" standard. That standard requires that a secured creditor be paid an amount equal to the value of the collateral, up to the amount owed. 45 If a secured creditor challenges the plan and the judgefinds it not to be fair and equitable, the judge will not confirm the plan and al low the reorganized firm to emerge from bankruptcy. ${ }^{46}$ Thus, whether a Chapter 11 plan is considered fair and equitable -- and therefore whether the proceeding can be brought to a conclusion -- will depend on the value of the secured creditor's collateral. 47

To continue our earlier example, suppose that the portion of Creditor's $\$ 100$ claim that is a secured claim will depend on the value of the machine - $\$ X$. If $\$ X$ is more than $\$ 100$, then Creditor has a secured claim of $\$ 100$. If $\$ X$ is less than $\$ 100$, then Creditor has a secured claim of $\$ X$. Thus, if the machine is worth at least $\$ 100$, the "fair and equitable" standard requires that Creditor receive $\$ 100$. If the machine is worth $\$ X$ (less than \$100), then Debtor must provideCreditor with \$X.

\section{The A bsence of a V erifiable Figure}

As we saw earlier, the value of assets serving as collateral must be determined by the end of the Chapter 11 proceeding. The problem, however, is that in the absence of a piecemeal liquidation there is no indisputable value for an asset serving as collateral.

45 See 11 U.S.C. $\S 1129(b)(1),(b)(2)(A)$. Chapter 7 does not specify what a secured creditor must receivein theevent that its collateral is sold as part of a going concern. However, it is believed that in such a case the judge would give the secured creditor the value of the collateral, up to the amount owed.

46 See Collier ON BANKRUPTCY § 1109.09 (2000).

47 In Chapter 11, a secured creditor may in certain cases el ect to treat its entire claim as a "secured claim" even if the amount of the claim exceeds the value of the collateral. See 11 U.S.C. $§ 1111$ (b). Sincethe secured claim is simply the amount owed the creditor, it might seem that there is no need to value the collateral. However, when the secured creditor makes the $\S 1111$ (b) election the plan proponent will decline to pay the secured claim in cash. Instead, the plan proponent will offer the secured creditor an interest-bearing note, in theamountof the entire claim, that is secured by the collateral. And, the "fair and equitable" standard requires that the present value of thepayments under thenotebeat least the amount of thepre-election secured claim (thelesser of thevalue of thecollateral and the amount ow ed). See 11 U.S.C. $§ 1129(b)(2)(B)$; EPSTEIN et.al., su pra note 6 at 775-779. Thus the value of collateral is an i mportantissueeven in thosecases where the amount of the "secured claim" is not in dispute as a result of a 11 U.S.C. $\S$ 1111 (b) election. Wewill assumethat the $\$ 1111$ (b) el ection is not in effect, and that $a$ secured creditor's claim must be broken into its "secured" and "unsecured" parts. This assumption does not affect any of the analysis. 
If the assets could beindividually auctioned during the proceeding, that procedure would yield an objective, verifiable amount for the value of each asset. 48 Each secured creditor would be paid the proceeds of the sale of its collateral, up to the amount owed. Nobody could complain about the value of the assets. If unsecured creditors believed that the auction price was too low, they could bid for the asset and then resell it at the higher "true" price. And even if for some reason the auction did not yield the highest possible price for the asset, there would still be no question of how to convert the secured creditor's claim into secured and unsecured claims.

However, in any business bankruptcy in which the assets are to remain as a going concern, the automatic stay prevents secured creditors from seizing and selling their collateral. 49 In the absence of such an auction sale, there is no indisputable, verifiable value for the collateral. And, inevitably, the lack of such a value leads to disagreement among the parties.

There may be both genuine and strategic reasons for the parties to disagree. Genuine disagreement may arise if there are heterogeneous estimates about the value of the asset. Returning to our example, Creditor might truly believethat themachineserving as its collateral is worth $\$ 120$, and therefore that Creditor is entitled to be paid $\$ 100$. Another party might sincerely believe that the machine is worth $\$ 80$, and therefore that Creditor is entitled to be paid $\$ 80$ for its secured claim. This divergence could arise because of differences in information or valuation capabilities among the parties.

Even if there is no genuine disagreement about the value of the collateral, the parties may have strategic reasons for advancing different estimates. The secured creditor whose collateral is being valued would generally benefit if, for purposes of the plan, the value is considered to be high. It will thus have an incentive to advance a high estimate of the value in negotiations or in litigation. 50 Unsecured creditors and equity holders will generally benefit from a low estimate because this reduces

48 See BAIRD, supra note 7.

49 As explained in Section A, if there were a sale of an asset during the bankruptcy, the debtor might not have the cash to purchase the asset even if the asset were worth moreto the debtor as a going concern than to anyoneelse. Thus, putting assets up for sale could destroy the asset's going concern value.

50 Occasionally, the secured creditor may benefit from having a deficiency claim that it can use to voteagainst, and prevent confirmation of, a plan it does not like. In such situations thesecured creditor would benefit from a valuation that is lower than the amount of the creditor's claim. In most cases, however, the secured creditor will prefer a high valuation. 
the payout to the secured creditor under the plan, leaving more of the bankruptcy piefor them.

The following simple numerical example illustrates this point. Consider a case in which there is a secured creditor who has a $\$ 100$ claim and unsecured creditors who have claims totaling $\$ 200$. Suppose all of the assets are sold as a going concern for $\$ 150$, and suppose that everyone knows that the collateral backing the secured loan has a value of $\$ 75$. In this case, the right division would be based on the secured creditor's having a secured claim of $\$ 75$ and a deficiency claim of $\$ 25$ to be pooled with the other $\$ 200$ in unsecured claims. The deficiency claim and all other unsecured claims would be paid pro rata with the $\$ 75$ that remains after the secured claim is paid; the unsecured creditors thus would get $33 \%$ of their claims paid.

However, the parties have clear incentives to advance valuations that they know to be higher or lower than the actual value of the collateral. The secured creditor might assert that the asset is worth $\$ 100$. If the asset were thought to be worth $\$ 100$, the secured creditor would be paid $\$ 100$ for its secured claim (leaving no part of its $\$ 100$ claim unsecured), and the remaining $\$ 50$ would be shared by the unsecured creditors, who would now get only $25 \%$ of their claims paid. In contrast, the unsecured creditors would have an incentive to claim that the collateral is worth only, say, $\$ 50$. If the collateral were considered to be worth $\$ 50$, the secured creditor would get only $\$ 50$ for its secured claim, leaving it with an unsecured claim of $\$ 50$. In such a case, there would be $\$ 100$ remaining after the secured claim is paid and $\$ 250$ of unsecured claims. Consequently, the unsecured creditors would get $40 \%$ of their claims paid.

When we put forward our mechanism in Part III, we will consider the situation in which the parties do not agree on the value of the collateral. As we will see, our mechanism works well even when there is disagreement -- whether the disagreement is genuine or strategic. Whatever the source of the disagreement, no participant, whatever the participant's estimate of the value of the collateral, would have a good basis for complaining that the collateral is under - or over-valued.

\section{Comparison to the Problem of $\mathrm{V}$ aluing the $\mathrm{D}$ ebtor as a $\mathrm{W}$ hole}

The problem of valuing assets serving as collateral is similar to the problem of valuing the debtor as a whole at the end of a Chapter 11 proceeding when the debtor is not sold for cash. Both valuations affect the division of value among the participants in the bankruptcy 
proceeding and in both cases participants have strategic incentives to advance self-serving valuations.

If there were an actual cash sale of the debtor to an outsider in Chapter 11, that sale would place a value on the debtor.51 Theliquidation would result in an exchange of the debtor's assets for cash. Whether or not this cash represents the "true" value of the assets sold, there would be no question as to the total value available for distribution and the proper payout to each class. The payout to each class would be determined by priority. Creditors with the highest priority would receive payment until either no money is left or their claims are paid in full; if the highest priority creditors are paid in full and there is money left, the next highest ranking creditors would receive payment until no money is left or their claims are paid in full, and so on. If all of the creditors were paid in full, any remaining cash would be distributed to equityholders.

However, when a debtor in Chapter 11 is not sold for cash, a fundamental problem of valuation arises.52 At the end of the proceeding at least some of the participants will receive securities in the reorganized corporation. 53 The value of the securities received by the investors will depend on the value of the debtor as a whole. But in the absence of a cash sale to a third party there is no verifiable, objective figure for the value of the reorganized firm. As a result, it is difficult to achieve agreement over the reorganization value of the debtor. And there is a clear conflict of interest among the participants which makes agreement all the more difficult.

To illustrate the problem, consider a simple example: Suppose a firm has two classes of unsecured creditors - "senior creditors" and "junior creditors" (who are subordinated to the seniorcreditors) - and the only other participants in the bankruptcy proceeding are the old equityholders. Suppose further that post-bankruptcy the firm will have an all-equity capital structure and that all claims will be paid with equity in the reorganized firm.

The senior creditors would have an incentive to argue for a low valuation of the firm, which would entitle them to a larger fraction of the equity in the reorganized firm. In contrast, the junior creditors would have an incentive to advance a higher valuation so that the senior creditors get a smaller fraction of the equity, leaving more for the junior creditors. However, they will not advance a value that is so high that

51 See JACKSON, supra note 13, at 211-12.

52 See Bebchuk, 0 ptions A pproach, supra note 14, at 778; Bebchuk, Chapter 11, supra note 14.

53 See EPSTEIN et. al., supra note 6 , at $\S 10$, at 731-80. 
they will be forced to share the equity with the old equityholders. Old equityholders will advance the highest valuation, a valuation that would entitle them to some of the equity.

\section{The Separate Problem of D elay}

Before proceeding, it should be noted that the absence of a verifiableand indisputablefigure for the value of collateral is not the only problem currently facing secured creditors in bankruptcy. Chapter 11 proceedings often last two or three years. ${ }^{54}$ During this time secured creditors are not al ways paid interest on their loans. 55 In addition, the value of the collateral may dedine and the court may fail to enforce the adequate protection provisions. ${ }^{56}$ Thus, even if the problem of valuing collateral did not exist -- that is, even if the value of the collateral always could be accurately determined at the end of the proceeding -- there might still remain the problem of systematic underpayment of secured claims due to the length of the proceeding.

Our analysis and proposal do not seek to address the problems of potential under-compensation of secured creditors caused by the length of the bankruptcy proceeding. ${ }^{57}$ Instead, our focus is on the problem of valuing collateral at the end of the proceedings, when the division of value must take place. Our proposed mechanism would place the parties in the same position as if a court had determined the value of collateral accurately and costlessly at the end of the proceeding. The problem of delay would still remain and need to be resolved in some other manner. ${ }^{58}$

\section{Existing $M$ ethods of $V$ aluing Collateral}

This section explains how collateral is currently valued when a firm is reorganized under Chapter 11 -- namely, through litigation and bargaining -- and the problems with this approach.

54 See infra Part II.C.2.

55 Secured creditors are entitled to post-petition interestonly to theextent that they are over-secured. See 11 U.S.C. § 506.

56 See Shal om L. Kohn, Recoupment Re-Examined, 73A M. BANKR. L.J. 353, 367 (1999).

57 However, to the extent the procedure we offer reduces the length of the bankruptcy proceeding by shortening the collateral valuation process, it would tend to reduce the valuation problems of secured creditors that arise from delay.

58 This could be done only by replacing Chapter 11 with a much faster bankruptcy procedure, such as one based on the options-based or auctions-based reform proposals, or by adopting a schemefor compensating secured creditors for the losses caused to them from delay. 
Currently, almost all business bankruptcies in which the firm is preserved as a going concern take the form of a reorganization under Chapter 11.59 In such a reorganization, the old debt and equity of the firm are cancelled and creditors (and sometimes equityholders) are given cash, debt, and equity in the firm emerging from bankruptcy. 60

The payouts to creditors at the end of Chapter 11 are made according to a "plan" of reorganization, which divides creditors' claims into "classes." 61 Each class consists of substantially similar claims. A secured creditor's secured claim will usually be put in its own class. ${ }^{62}$ If the secured creditor also has an unsecured claim, that claim may be placed in a class with other unsecured claims. 63 The payout to the class is distributed pro rata.64 The proceeding ends when theplan is "confirmed" by the bankruptcy judge. 65

Before the plan can be confirmed, creditors and equityholders vote on the plan. If a sufficient number of creditors (or equityholders) in a class votes in favor of the plan, that class is deemed to accept the plan. ${ }^{66}$ For the plan to be confirmed, it is not necessary that all of the classes vote in favor of the plan. As will be explained in more detail shortly, if one or more classes object the plan can be "crammed down" over their objection.

However, an objecting secured creditor -- whosesecured claim is in a class by itself -- can block a cram down by showing that the plan is not "fair and equitable" with respect to its secured claim. ${ }^{67}$ As briefly noted above, a plan does not meet this fair and equitable standard if the payout

59 M anagers interested in preserving the going concern valueof thefirmprefer Chapter 11 to Chapter 7 because Chapter 11 allows them to remain in control of the firm as debtor-in-possession whileChapter 7, by requiring appointment of a trustee, does not. See 11 U.S.C. §§ 701-04; 11 U.S.C. § 1107. See also Baird, supra note 13, at 139 (observing that there are very few sales of going concerns in Chapter 7).

60 EPSTEIN et al., supra note 6, at 756.

6111 U.S.C. $\S 1122(a)$.

62 See Elizabeth WARRen, Business BankRuptcy 30, 128 (1993).

63 Unsecured claims may be grouped together, or separated into different classes. See 11 U.S.C. § 1123(a)(1).

64 Id. $§ 1123(a)(4)$. A creditor may consent to being treated worsethan other class members. Id.

65 Id. $\S 1128$.

66 A class of creditor claims is considered to accept the plan if creditors constituting more than one half the members of the class and holding at least two thirds of the claims (by dollar amount) vote in favor of the plan. Id. $\S 1126$ (c).

67 ChARLESJORDAN TABB, THE LAW OF BANKRUPTCY 862 (1997). 
to be made on account of the secured claim is less than the amount of the secured claim.68 Thus, the secured creditor that has voted against the plan can attempt to block confirmation by arguing that its secured claim is greater than the value of the payout the creditor is to receive on account of that claim.

Resolving this challenge usually will requirethe court to conduct a valuation of the collateral.69 Each side will offer one or more experts to testify about the value of the asset. Each expert will present a view that favors his client. The judge will consider the testimony and reach her own conclusion about the value of the collateral.

However, litigation over the value of an asset is costly and time consuming for the parties. It is also risky for those who have the most at stake -- both the secured creditor and the plan proponent -- because the court could arrive at a valuation that is very low or very high relative to what they believeis the "true" value. Thus, theparties will al most al ways first attempt to reach an agreement on the value of the collateral through bargaining. 70

The bargaining may be successful. If the secured creditor believes that it is being offered at least what it would get in litigation (discounted for time, litigation expense, and risk), it may agree to vote for the plan rather than challenge the plan under the fair and equitable standard. In this situation bargaining will, everything else equal, shorten the length of the reorganization.

However, the bargaining ultimately may not lead to an agreement. In such a case, after the bargaining fails, the parties will have to litigate the value of the collateral. As a result, bargaining may actually prolong the length of the Chapter 11 proceeding..$^{71}$

68 For a plan giving deferred cash payments on account of a secured claim to be fair and equitable, the holder must also be allowed to retain its lien on the collateral or an adequate substitute. 11U.S.C. § 1129(b)(2)(A)(i)(I). A plan may also be considered fair and equitable for the holder of a secured claim if the holder receives something of the "indubitable equival ent" valueas thesecured claim. Id. $\S 1129(\mathrm{~b})(2)(\mathrm{A})(\mathrm{iii})$.

69 If the parties also disagree on the value of the note the secured creditor is to receive, then the court will be required to assess the value of the note as well.

70 It has been argued that the expense of conducting valuations through litigation is desi rable because it encourages negotiation. See Steven L. Schwarc, Sovereign D ebt Restructuring: A Bankruptcy Reorganization A pproach, 85 CORNELL L. REV. 956, 1007 (2000). But, as will shortly be explained, negotiations are not costless. In particular, they increase the length of the proceedings, which in turn increases the direct and indirect costs associated with bankruptcy.

71 In a recent paper, Barry A dler puts forward an intriguing proposal for improving the process of bargaining over collateral value in Chapter 11. SœBarry 


\section{The Shortcomings of Litigation and Bargaining}

There are two problems with using litigation and bargaining to value collateral in bankruptcy. First, they are likely to lead to deviations from parties' bankruptcy entitlements. 72 If there islitigation to judgment, the court's estimate of the value of the collateral is likely to be either too high or too low. If there is successful bargaining, the outcome may depend not only on the parties' entitlements but also on the relative strengths of their bargaining positions. For example, if the secured

A dler, "A SimpleG ame-Theoretic Solution to the Tension between Cramdown and $\mathrm{H}$ oldup in Corporate Reorganization" (working paper, 2000). Under A dler's proposal, the proponent of a Chapter 11 plan would makesimultaneous take-it-or-leaveitoffers to all of the secured creditors for their secured claims. The offerscould bein cash and/ or securities. If all of the secured creditors whose collateral is necessary for reorganization accept the offer, the debtor would keep thoseassets and reorganize. If one or more of these secured creditors refuses the offer, thedebtor would turnall of the assets over to the secured creditors and liquidate.

Although A dler's proposal would reducetheamount of timespent bargaining over the value of collateral, it is unclear whether it would lead to an overall improvement in the Chapter 11 bargaining process. Onemight beconcerned that the faster resolution would come at the expense of a significant amount of inefficient liquidation in Chapter 11 . The inefficient liquidation would result from parties having different estimates of thevalue of thecollateral. Consider the casein which continuation would be efficient, and one of the firm's secured creditors overestimates the liquidation value of its collateral (or, al ternatively, the plan proponent underestimates the liquidation valueof thecollateral). In such a case, the plan proponent might offer a price which the proponent believes is above the liquidation value of the asset but which the creditor believes is below the liquidation value. The secured creditor would then reject the offer, forcing the entire firm to inefficiently liquidate before the end of the Chapter 11 proceeding. The very finality of the take-it-or-leave-it mechanism that is at the heart of A dler's proposal would make it impossible to correct such a mistake (Itisworthnoting in this connection that, as Part III will show, our valuation mechanism does not lead to inefficient liquidation or the destruction of any val ue when bankruptcy participants have heterogeneous val uations for the collateral.) For thepurposes of our analysis, it is not necessary to resolve whether adopting A dler's proposal would or would not reduce the costs associated with the Chapter 11 bargaining process. What is important to observe is only that, even if Adler's proposal wereadopted, there would still be substantial costs associated with Chapter 11 bargaining.

72 By "entitlement," wemean what the secured creditor is entitled to get for its secured claim at the end of the proceeding, which we assume is the foreclosure value, up to the amount owed. Weabstract from the fact that because of thelength of the proceeding and the time value of money the secured creditor gets less than what it may have been entitled to at the beginning of the proceeding. Seesupra Part II.B.4. 
creditor has more to lose from delay, it may be forced to accept a valuation that is too low.73 Or, if the parties expect that the judge will overvaluethecollateral, the secured creditor can forcethe other parties to accept a valuation that is too high.

Second, litigation and bargaining indirectly give rise to costs by prolonging the bankruptcy. The reorganization process under the existing rules takes substantial time. ${ }^{74}$ Some Chapter 11 reorganizations last two, three, or even more years. 75 Although most of this delay is not attributable to litigation or bargaining over the value of collateral, both add to the length of the reorganization proceeding.

Prolonging the proceeding increases the total direct costs of bankruptcy. These direct costs include administrative costs, such as the fees paid to bankruptcy lawyers, accountants, and other professionals.76 For a large public company, such direct costs can reach $1.5 \%$ to $6 \%$ of total

firm value. ${ }^{77}$ As a result, they can run from several million dollars to hundreds of millions of dollars. 78

73 Thereis substantial evidencethat equityholders areableto usethethreat of delay to extract valuefrom creditors. Even though under the absolute priority rule equityholders are not to be paid unless the creditors arefirst paid in full, in many reorganizations equityhol ders receivevalueeven though creditors are not paid in full. See Lawrence A. Weiss, TheBankruptcy Codeand V iolations of A bsoluteP riority, 4 J. A PPLIED CORP. FIN. 71, 73, 75-76 (1991).

74 See, e.g., Robert Gertner \& David Scharfstein, A Theory of W orkouts and the Effects of Reorganization Law, 46 J. FIN. 1189, 1212-15 (1991); LoPucki \& Whitford, supra note 5; Lawrence. A. Weiss, Bankruptcy R esolution: D irect C osts and V iolation of Priority of Claims, 27 J. FIN. ECON. 285 (1990).

75 See Lynn M. LoPucki, The Trouble with Chapter 11, 1993 WIS. L. REv. 729, 74044.

76 When there is litigation over the value of collateral, these administrative costs are even higher.

77 See Ferris and Lawless, TheExpenses of Financial D istress: The D irect Costs of Chapter 11, 61 U. PITT. L. R EV. 629, 662 (2000) (finding median direct costs of $4.7 \%$ in sample of 118Chapter 11s that wereinitiated throughout theU.S. during theperiod 1986-1993); Weiss, supra note 74 (finding mean direct cost in bankruptcy reorganizations of 37 NYSE and AM EX firms between 11/ 79and 12/ 86 was 2.8\% of total book value of assets); Edward I. A Itman, A Further Empirical Investigation of the Bankruptcy Cost Q uestion, 39J. FIN. 1067, 1078 (1984) (finding direct costs to be an average of $6.2 \%$ of asset value). Even prepackaged bankruptcies are costly. See Tashjian et al., Prepacks: A n Empirical A nalysis of Prepackaged Bankruptcies, 40 J. FIN. EcON. 135, 144tbl. 2 (1996) (finding that the mean cost of prepackaged bankruptcy reorganizations of 49 public companies from 10 / 86 to 6192 was $1.85 \%$ of the total book value of assets). 
More importantly, the reorganizing company is likely to incur substantial "indirect" costs from functioning inefficiently during the reorganization process.79 For example, the incentives of management during the bankruptcy proceeding are often not well aligned with the maximization of reorganization value. Thus, management decisionmaking during the process is likely to be distorted. 80 In addition, because of the insolvency cloud hovering over the company, potential business partners may bereluctant to invest in developing a long-term relationship with the firm. Thelonger litigation and bargaining make the proceeding, the higher are these indirect costs, which are believed to be much higher than the direct costs. 81

\section{The V aluation Problem U nder M arket-Based R eforms}

Because Chapter 11 reorganization proceedings generally produce deviations from parties' entitlements and costly delays, two types of market-based alternatives to Chapter 11 have been suggested: the auctions approach and theoptions approach. ${ }^{22}$ A s will beexplained, each of these alternative approaches eliminates the problem of valuing the debtor as a whole that was described in section B. As a result, each of these atternatives might be able to shorten the length of bankruptcy proceedings and to bring the division of value closer to one that reflects parties' entitlements. However, as will be discussed below, neither of these alternatives solves (or was ever intended to solve) the problem of valuing collateral. Each of theseapproaches still requires that the amount of each secured claim be determined. And it has thus far been believed that even under such market-based reforms, collateral value would inevitably continue to be determined the way it is now -- through timeconsuming and costly litigation and bargaining. On this score, the proposals were regarded by their own proponents as no better -- though also no worse -- than Chapter 11.

78 See, e.g., Lynn M. LoPucki, Cooperation in International Bankruptcy: A PostU niversalist A pproach, 84 CORNELL L. REV. 696, 713 n. 87 (1999) (noting fee of $\$ 200$ million paid to the English liquidators of $\mathrm{BCCl}$ ).

79 See David A. Skeel, Jr., Markets, Courts, and the Brave N ew World of Bankruptcy Theory, 1993 WISC. L. REV. 465, 472.

80 See Lynn M. Lopucki \& William C. Whitford, Corporate Governance in the Bankruptcy Reorganization of Large, Publicly Held Companies, 141 U. PA. L. REv. 669 (1993).

81 See LOPUCKI \& KALIN, supra note 8, at 7.

82 Bebchuk, Chapter 11, supra note 14, at 221-23. 


\section{The A uctions A pproach}

Under the auctions approach, which was put forward by Douglas Baird and Thomas Jackson,83 the debtor's assets would always be put on the block and auctioned off for cash. Currently, in a small number of Chapter 11 bankruptcies, firms are sold for cash as going concerns rather than reorganized.84 The auctions approach would eliminate the possibility of financial reorganization and require that all businesses be either sold for cash as going concerns or liquidated piecemeal.85 The auctions approach can thus be regarded as suggesting a drastic change in the rules of Chapter 11 , or as suggesting the elimination of Chapter 11 altogether and effecting sales of bankrupt firms through the rules of Chapter 7.

Under the auctions approach, once the cash is paid to the auctioneer, it would be available for distribution to the participants in accordance with the ranking of their priorities. In contrast to a reorganization in which part or all of the payout is in the form of stock, it will be immediately apparent to all of the participants how much valueis available for distribution to all of the participants and how much value each creditor is receiving. Thus, in contrast to a non-cash reorganization, there will be no need to litigate or negotiate the value of the debtor in order to determine the value of the debtor's securities.

H owever, the auctions approach does require first determining the composition of the different classes so as to establish the ranking of priorities according to which the money will be distributed. Under the principle of full priority, secured creditors areentitled to thevalue of their collateral, up to the amount of their claim; 86 if therewere a deficiency, the secured creditor would have an unsecured claim that would share pro rata with other unsecured claims. ${ }^{87}$ Thus, as under Chapter 11,

83 See Baird, supra note13 (arguing that bankrupt firms should beliquidated or sold as going concerns to prevent opportunistic behavior by theparties and to avoid the potential distortions resulting from a fictive valuation of the firm); JACKSON, supra note 13, at 224. See also Michael C. Jensen, Corporate Control and the Politics of Finance, 4J. A PPLIED CORP. FIN. 13, 31-32 (Summer 1991) (advocating auctions in bankruptcy as a moreefficient way of determining the value of bankrupt firms as a going concern and solving the problems of information asymmetry and perverse incentives of various claimants).

84 Although in principleChapter 7 could be used to sell the debtor as a going concern, it rarely is. See Baird, supra note 13, at 139.

85 See id. at

86 See Bebchuk \& Fried, supra note 18, at 862.

87 See 11 U.S.C. § 506 (1994). 
implementing the auctions approach requires valuing each secured creditor's collateral before the end of the proceeding.

In the absence of any market-based procedure for valuing collateral, then, an auctions regime would need to use existing valuation methods to determine the values of the collateral before the auction proceeds are divided. In other words, any auctions regime would be forced to rely on litigation and bargaining to perform this essential function. Indeed, believing that no market-based approach to valuing collateral was possible, a prominent proponent of the auctions approach has viewed the problem of collateral valuation as one of the main impediments to implementing market-based reforms in bankruptcy. 88

\section{The 0 ptions A pproach}

The other market-based alternative to Chapter 11, proposed by one of us in earlier work, is the "options approach."89 Under the options approach, the participants in a reorganization would receive options on securities in the reorganized firm according to their priority rankings. The class consisting of the highest-ranked claimants initially would be given $100 \%$ of the equity of the reorganized firm. However, the next highest-ranked claimants would have the right to buy these equity interests by paying the claims of the highest-ranked claimants in full, and so on.

For example, suppose (as in our earlier example) that there are three types of participants in the bankruptcy proceeding: senior (unsecured) creditors, junior (unsecured) creditors (who aresubordinated to the senior creditors), and old equityholders. Senior creditors would initially receive $100 \%$ of the equity. However, junior creditors would have the right to buy the equity by paying in full the senior creditors' claims. Old equityholders would have the right to buy the equity in the reorganized firm by paying off both the junior and senior creditors' claims. The call options distributed to the junior creditors and the equityholders would be distributed pro rata. Thus, for example, an equityholder who owned $5 \%$ of the pre-bankruptcy equity would havean option to buy $5 \%$ of the post-bankruptcy equity. It would exercise the option by paying in full $5 \%$ of the junior claims and $5 \%$ of the senior claims.

88 See BAIRD, supra note 7, at 13-14. A similar view was expressed by Mark Roe, who was an early advocate of making certain use of auctions. See Roe, supra note 13.

89 See Lucian A. Bebchuk, 0 ptions A pproach, supra note 14, and other works cited supra note 14. 
Because the division of value among the classes, and among individual creditors, would result from the participants' own decisions concerning the exercise of the options given to them, nobody could complain that they were being treated unfairly. For example, if thesenior creditors were to end up with $100 \%$ of the equity, a junior creditor could not arguethat the equity was worth morethan thesenior creditors' claims and, consequently, that the senior creditors were overpaid and that the junior creditors were underpaid. If a junior creditor owning, say, 5\% of the junior debt believed that the equity was worth more than the senior creditors' claims, it could buy $5 \%$ of the equity by paying in full $5 \%$ of the senior creditors' claims. The junior creditor would thereby get its entitlement: namely its pro rata share of the amount by which the reorganization value exceeds senior claims, up to the amount owed the junior creditor. As under the auctions approach, there is no need to value the payout received by each creditor class to ensure that priority is respected. Thus, there would be no need to value the debtor. However, in contrast to the auctions approach, the options approach would not require the existence of a party that could pay in cash for the entire firm.

Although the options approach obviates the need to value the debtor as a whole, it does not eliminate the need to value collateral. Like the auctions approach, the options approach requires that each participating claim be rank-ordered relative to all other claims. $90 \mathrm{~A}$ secured creditor's claim has priority over all other claims only to the extent that it is secured; the remainder is an unsecured claim that ranks equally with other unsecured claims. ${ }^{91}$ Thus, a secured creditor's claim must first be broken into a (fully) secured claim and an unsecured claim. As a result, the options approach cannot be implemented until the value of collateral is first determined.

Earlier accounts of the options proposal noted explicitly that collateral would need to bevalued prior to allocation of the options, and expressed the belief that this would be done using existing methods. ${ }^{92}$ That is, the options proposal offered to do no better on this score -though of course no worse -- than Chapter 11.

90 See Bebchuk, 0 ptions A pproach, supra note 14, at 802 (noting that theoptions approach requires that secured creditors' claims first be broken into secured and unsecured claims); Skeel, supra note 79, at 481.

91 See supra Part II.A.2.b.

92 See Bebchuk, Options Approach, supra note 14, at (making such observations); Aghion et. al., supra note 14, at (same). 


\section{The $V$ aluation Problem as Impediment to $M$ arket-Based R eforms}

Much of the scholarly interest in bankruptcy literature in the last fifteen years has focused on attempts to devisemarket-based reforms that would eliminate the need for litigation and bargaining. ${ }^{93}$ But as some of the partici pants in this enterprise have recognized, these reforms cannot eliminate litigation and bargaining altogether as long as these methods are still required to value collateral. ${ }^{94}$ And because it has been generally believed that the use of these methods to value collateral is inevitable, it seemed that market-based reform could not completely eliminate litigation and bargaining. Thus, if it is possible to valuecollateral without resort to litigation and bargaining, as we now turn to show is the case, that would contributeto attaining the aspirations of the literature seeking market-based reforms. Indeed, sincewewill also show that this valuation mechanism could be combined with either the auctions or options approaches, this mechanism could become a significant element in any market-based reform of bankruptcy.

\section{The Proposed Approach}

This Part sets forth our proposed approach to valuing collateral in bankruptcy. Section A puts forward a reconceptualization of a secured creditor's claim which underlies our approach. We explain why the amount of the creditor's claim that is (fully) secured -- its secured claim- is equal to the value of a nonrecourse note, backed by the collateral, for the amount of the creditor's total claim. Section B provides a brief introduction to the proposed mechanism for valuing the secured claim and its three basic stages. Section $C$ describes the first stage, which is an auction of a nonrecourse note that takes place shortly before the end of the bankruptcy proceeding. That auction determines the value of the nonrecourse note and therefore the amount of the secured claim. Section $D$ focuses on the second stage, which is the subsequent division of the bankruptcy pie that is made on the basis of the information generated at the first stage. The distribution completes the bankruptcy proceeding. Section E considers the third and final stage, which is theresolution of the nonrecourse note immediately after the end of the proceeding.

We then turn to three sections that present extensions, generalizations, and an alternative version of the mechanism. In our

93 See, e.g., Baird, supra note 3, at 128; Bebchuk, su pra note14, at 776; Roe, supra note 13 , at 528 .

94 See, e.g., RoE (2000), supra note 15 , at 
initial exposition of the mechanism, we assume for simplicity that the second stage of the mechanism -- the division of the bankruptcy pie -takes place under an auctions regime in which the debtor is sold for cash. Section $\mathrm{F}$ therefore explains how our mechanism can also be used under the other two regimes for dividing the bankruptcy pie -- bargaining (Chapter 11) and options. Section G presents an alternative version of our mechanism under which there is no auction of the nonrecourse note. Instead, the secured creditor is given the nonrecourse note in satisfaction of its secured claim and bargains with the debtor after the bankruptcy proceeding. Section $\mathrm{H}$ shows how our mechanism could be used to implement partial priority if such a rule were ever adopted.

\section{A. Reconceptualizing the Secured Creditor's Claim}

As we saw in section II.A., a secured creditor's bankruptcy claim is bifurcated into two components: a secured claim and, if the value of the collateral is less than the amount owed, an unsecured claim. The secured claim is an amount equal to the value of the collateral, up to the amount owed the creditor. It must be paid in full at the end of the bankruptcy proceeding. ${ }^{95}$ In our example, in which Creditor has extended a loan for $\$ 100$ collateralized by a machine with a foreclosure value of $\$ X$, Creditor has a secured claim for the lesser of $\$ X$ and $\$ 100$. The unsecured claim is simply the amount owed less the secured claim. Thus if $\$ X$ is less than $\$ 100$, Creditor has both a secured claim of $\$ X$ and an unsecured claim of $\$ 100-\$ X$.

A nonrecourseloan is a secured loan whose terms forbid thelender from collecting the deficiency from the defaulting debtor when the amount owed exceeds the value of the collateral.96 It is called a nonrecourse loan because the lender has no recourse against the debtor other than seizing the collateral. In our example, the \$100 loan extended by Creditor to Debtor would be nonrecourse if Creditor could satisfy its $\$ 100$ claim only by seizing and selling the collateral. If Creditor could satisfy its $\$ 100$ claim only in that way, and if $\$ X$ is less than $\$ 100$, that nonrecourse Ioan (if due immediately) would be valued at $\$ X$ because that is themost Creditor could get in satisfaction of the loan. If $\$ X$ is more

95 As was explained above, see supra Part II.A.2.b, payment may bein theform of cash or a notesecured by thecollateral whose value is at least the amount of the secured claim.

96 For a general description of the use of nonrecourse loans, see Gregory $M$. Stein, Nonrecourse Loans, 442 PLI ReAL Estate LAW AND Practice Course H ANDBook SeRIES (1999). See also Steven L. Schwarcz, TheE asy CaseF or TheP riority Of Secured Claims In Bankruptcy, 47 DUKE L. J. 425, 462-463 (1997). 
than $\$ 100$, the nonrecourse loan would be worth $\$ 100$ because were Creditor to seize and sell the collateral, it could keep only the first $\$ 100$ of the sale proceeds. Thus, the loan would have a value of the lesser of \$X and \$100: the value of the collateral, up to the amount owed. ${ }^{97}$

Therefore, if Creditor had lent to Debtor on a nonrecourse basis, the value of the nonrecourse note (if due immediately) would be the same as the amount of Creditor's secured claim. Conversely, Creditor's secured claim can be thought of as the value of a $\$ 100$ nonrecourse loan secured by the machine.

The equivalence between the amount of a secured claim and the value of a nonrecourse loan is, of course, not limited to this particular example. Any secured claim can be thought of as the value of a nonrecourse note for the amount owed the creditor, backed by the same collateral.

And because the unsecured claim of a secured creditor (if any) is simply the amount owed less the secured claim, this unsecured claim can be thought of as the amount owed the creditor less the value of the corresponding nonrecourse loan. In our example, Creditor's $\$ 100$ claim is thus the same as a secured claim equal to the value of a $\$ 100$ nonrecourse loan secured by the machine, and an unsecured claim equal to $\$ 100$ less the value of that nonrecourse loan.

Thefollowing diagram illustrates our reconceptual ization of a $\$ 100$ claim secured by a machine worth $\$ X$.

\begin{tabular}{|l|l|l|}
\hline & In bankruptcy & Reconceptualization \\
\hline $\begin{array}{l}\text { A mount of } \\
\text { Secured daim }\end{array}$ & Lesser of \$X and \$100 & $\begin{array}{l}\text { Value of nonrecourse } \\
\text { note for \$100, backed } \\
\text { by machineworth \$X }\end{array}$ \\
\hline $\begin{array}{l}\text { Amount of } \\
\text { Unsecured claim }\end{array}$ & $\begin{array}{l}\text { \$100 less amount of } \\
\text { secured claim }\end{array}$ & $\begin{array}{l}\text { \$100 less value of } \\
\text { nonrecourse note }\end{array}$ \\
\hline
\end{tabular}

B. The M echanism and its Three Stages

We wish to start by outlining the three main elements of the mechanism. While each of these elements will be discussed in more detail later, it will be useful to first provide an overview of the entire

97 We assume the loan is due immediately. If the loan were not due immediately, its value would be discounted to reflect the time value of money. 
mechanism. As section A explained, the amount of a secured claim is simply the value of a nonrecourse note (for the amount owed the secured creditor) secured by the collateral. If the debtor firm were solvent we could determine the value of the nonrecourse note by treating the note as due immediately and observing how much the debtor firm would be willing to pay to keep the collateral. Resolution of the nonrecourse note would not result in a loss of going concern value: if the collateral were worth more to the debtor than to other parties, the debtor would be able to afford to "buy" the asset from the noteholder and the asset would remain in the debtor's hands.

During a bankruptcy proceeding, however, the debtor may not have the financial ability to redeem the collateral. As a result, making the note payable immediately could force the debtor to relinquish the asset even if the asset has going concern value for the debtor. This forced relinquishment, in turn, would give rise to a social cost and reduce the size of the pie available to all of the debtor's investors.

Our mechanism addresses this problem by separating in time the valuation of the nonrecourse note from the resolution of the note. In particular, we propose to defer the resolution of the nonrecourse loan until after the debtor firm has emerged from the bankruptcy proceeding as a solvent firm. At that time, resolution of the note should lead to an efficient outcome. However, the valuation of the note would be effected through an auction of the nonrecourse note before the completion of the bankruptcy proceeding. As we will explain in more detail, this auction would provide the information needed to divide a secured creditor's claim into a secured claim and an unsecured claim which, in turn, is needed to distribute the bankruptcy pie and bring the bankruptcy to an end.98 The timelinewould be as follows:

\begin{tabular}{|l|l|l|}
$\begin{array}{l}\text { 1. Auction } \\
\text { of nonrecourse } \\
\text { loan }\end{array}$ & $\begin{array}{l}\text { 2. Distribution } \\
\text { of bankruptcy } \\
\text { pie }\end{array}$ & $\longrightarrow \begin{array}{l}\text { 3. Resolution } \\
\text { of nonrecourse } \\
\text { loan }\end{array}$ \\
\hline
\end{tabular}

In the first stage, which would take place shortly before the end of the bankruptcy proceeding, the nonrecourse note is auctioned. As will be

98 When we put forward the al ternative, non-auction version of themechanism in Part III.G., we will explain how, when thefirm is sold for cash, both thevaluation of the noteand the resolution of the note can be effected simultaneously after the end of the bankruptcy proceeding. 
explained in section $\mathrm{C}$ below, anyone -- including both bankruptcy participants and outsiders -- could participatein the auction. Theauction would establish the value of the nonrecourse note and, therefore, determine the amount of the creditor's secured claim (and unsecured claim). As we will show, the auction price should reflect the foreclosure value of the collateral, up to the amount of the claim, theamount to which the secured creditor is entitled. The cash raised would beset aside to pay the secured claim at the end of the proceeding when all other claims are paid.

In the second stage, the bankruptcy pie is divided and distributed, using the information generated by the auction. Although our solution to the problem of valuing secured claims could be used under any method for dividing the bankruptcy pie -- Chapter 11, auctions, or options -- for purposes of illustration we will describe how the proposal operates when the bankruptcy pie that is divided and distributed consists of the proceeds of a cash sale of the debtor as a going concern. Such sales, which currently take place in Chapter 11, would be mandatory under the auctions alternative to Chapter 11 . As section D will explain, the firm would be sold subject to the nonrecourse note. 99 The cash raised at the prior auction of the nonrecourse note would be used to pay the secured creditor's secured claim. The cash raised from the sale of the debtor firm would be used to pay the creditor's unsecured claim, if any.

The third and last stage is the resolution of the nonrecourse note immediately after the debtor firm has emerged from bankruptcy. After bankruptcy, the holder of the nonrecoursenote-- thehighest bidder at the auction -- will have the right to seize the asset, sell it at an auction, and keep the proceeds up to the face amount of the note. As will be explained in section $E$, the note will be resolved in one of three ways: (1) if the foreclosure value exceeds the face amount of the note, the debtor will pay the noteholder the face amount of the note; (2) if the foreclosure value is less than the face amount but more than the value of the asset to the debtor, the debtor will let the noteholder seize the asset, who will then sell theasset and receivetheforeclosurevalue; or (3) if the foreclosurevalueis less than the face amount of the debt and less than the value of the asset to the debtor, the debtor will pay the noteholder the foreclosure value and keep the asset. Thus, the noteholder will get the foreclosure value of the asset, up to the face amount of the note. And the debtor firm will end up retaining the asset if and only if it is the highest valuing user - in other words, the resolution of the nonrecourse note will be efficient.

99 The firm would also besubject to other nonrecourse notes if thereare other assets serving as collateral. 


\section{First Stage: The A uction of the $\mathrm{N}$ on recourse $\mathrm{N}$ ote}

\section{The Conduct of the A uction}

The aim of the auction is to establish a value for the nonrecourse notecorresponding to the secured creditor's secured claim. As explained, this value will indicate the amount of the secured claim, and therefore allow the secured creditor's claim to be divided into its secured and unsecured components. For each secured creditor whose collateral needs to be valued, a note would be drafted that gives its holder the right to receive from the debtor the amount owed the secured creditor. The noteholder would have recourse only to the secured creditor's collateral. The note would be due shortly after the end of the bankruptcy proceeding.

The auction of the nonrecourse note would take place just before the completion of the bankruptcy proceeding. As will be further discussed in section $D$, at the end of the bankruptcy proceeding, when all other claims are paid, the cash generated by the auction would be used to pay in full the secured creditor's secured claim. In the very brief period between the auction of the nonrecourse note and the payment to the secured creditor, the monies received for the non-recourse note would be held in a separate (interest-bearing) account.100

The auction would be open to any claim- or interest-holder (or group of claim- or interest-holders) in the bankruptcy proceeding. Thus, for example, the secured creditor, other secured and unsecured creditors, the unsecured creditors' committee, and equityholders could participate. In addition, the debtor itself (through its managers, acting as debtor-inpossession, or a trustee) would be allowed to bid on the note. Finally, the auction would beopen to all outside parties.

The winning bidder would be required to make its bid in cash. The cash would bedeposited in an (interest-bearing) escrow account and used to pay off the corresponding secured claim upon completion of the bankruptcy proceeding. However, two parties would beexempt from the cash-only rule: the secured creditor and the debtor. In forecl osure sales of repossessed collateral outside of bankruptcy, a secured creditor is generally permitted to "bid-in" without putting up cash because a cash bid by the secured creditor would be equivalent to moving money from

100 A s will be explained later, the interest generated on the funds would be given to the winning bidder at theend of the proceeding. Theinterest compensates the bidder for the time value of its money during the short period between the auction of the nonrecourse note and the resolution of the note. 
one pocket to another. ${ }^{101}$ Similarly, a secured creditor would bepermitted to participate in the auction of the nonrecourse note simply by specifying the amount of its bid. As will be explained below, permitting the secured creditor to bid-in would not distort the outcome of the auction. In addition, the debtor could bid with a note that is due immediately after theend of the bankruptcy proceeding. Because the debtor will be solvent it should have no difficulty paying this note.

\section{The $V$ alue of the A uctioned $N$ ote}

We shall in subsections 3 and 4 explain why providing each participant in the bankruptcy proceeding -- as well as parties representing their interests -- with theopportunity to participate in the auction would largely ensure that the outcome of the auction is consistent with parties' entitlements -- even if there are very few knowledgeable parties bidding at the auction.

However, there is every reason to expect that these auctions would attract significant participation by liquid and fully-informed bidders. Because the nonrecourse note will yield the winning bidder either cash or the collateral shortly after the bankruptcy proceeding, estimating the value of the note will be no more difficult for a bidder than estimating the value of the collateral. It tends to be relatively easy for knowledgeable parties to estimate the value of and liquidate (that is, convert into cash) the kinds of assets that are commonly used as collateral -- real estate, vehicles, equipment, accounts receivable.102 Auctions of nonrecourse notes should therefore attract the same types of bidders that have sufficient cash and information to participatein auctions of theseassets in and outside bankruptcy. To begin with, the auctions are likely to draw many of the creditors involved in the bankruptcy proceeding -- such as banks, finance companies, and suppliers -- that have capital and, since they lend in the firm's industry, the ability to value the collateral. When the collateral is of sufficiently significant value, outside bidders are likely

102 See Bill B. Caraway, U nwrapping theW raparound M ortgageForeclosure Process, 47 W ASH . \& L EE L. Rev. 1025, 1038 (1990) (noting that non-cash bidsareallowed in foreclosures on mortgages).

102 For example, real estateinvestors would bid on nonrecoursenotes backed by Iand and buildings. Cf. Michael Korybut, O nline A uctions of Repossessed Collateral under A rticle 9, 31 RutgERS L.J. 29, 29 (1999) (explaining how the Internet increases the number of bidders in foreclosure sales outside bankruptcy by all owing remote bidding). 
to be attracted to the auctions of the nonrecourse notes as well.103 Shortterm credit, perhaps secured by the nonrecourse note, should be readily available to bidders who wish to purchase the notes at auction and convert them into cash shortly thereafter. This, in turn, should increase the number of knowledgeable parties that are able to participate in the bidding.

When there are a number of well-informed bidders at the auction, the note that is auctioned can be expected to fetch a price that reflects its value to a person holding the note. As will be discussed in section $E$, the party that becomes the holder of the nonrecourse note can be expected to get, shortly after the end of the bankruptcy proceeding, the foreclosure value of the collateral, up to the face amount of the loan (which is, again, the amount of the secured creditor's original claim). Because the auction will be taking place just before the completion of the bankruptcy proceeding, and thus shortly before the resolution of the nonrecourse note, the auction price of the note should "reflect" quite well the amount that the noteholder is expected to get- that is, theforeclosurevalue of the collateral, up to the amount owed. ${ }^{104}$. Consequently, the auction of the nonrecourse note will generate a price that is equal to the amount of the secured creditor's secured claim. A ccordingly, the proceeds to the auction can be used to pay the secured creditor in full for its secured claim. By determining the amount of the secured claim, the auction will also

103 If the value of the collateral exceeds the amount owed, the nonrecourse note will essentially be equivalent to a no-risk loan that is about to become due. A uctions of such notes should al so attract arbitrageurs hoping to profit from slight disparities between the auction price and the face amount of the loan.

104 By "predict," wedo not mean that theauction pricewill perfectly reflect the expected value of thenoteto the noteholder. Therewill tend to bea slight discount that provides the bidder with whatever small profit is necessary to compensate the bidder for therisk of changes in the value of the collateral during the period of time between the aucti on and the resolution of the nonrecourse note. But because this period will be very short, the discount should be quite small.

Onemight beconcerned that therewould bean additional discount because of the time value of money. In particular, because a period of time will elapse between theauction and theresolution of the note, theauction pricewill not equal the amount that the noteholder expects to get at the end of the proceeding but rather the present value of that amount. However, as explained earlier, thecash paid by the winner of the auction would remain in an interest-bearing escrow account until the end of the proceeding, at which point the interest would be returned to the bidder. Thus, the winning bidder would be compensated for the time value of its money and therefore not discount its bid on account of this consideration. Even if interest were not paid to the bidder, the period of time between the auction and resolution is likely to be so short that any time-value-ofmoney discount would be trivial. 
determine the amount of the unsecured claim, if any, that the secured creditor has (which, as was explained, is simply the difference, if any, between the secured claim and the amount owed).

In our example, the auction of the nonrecourse loan backed by the machine should fetch the lesser of $\$ X$ and $\$ 100$. The amount paid by the winning bidder will be given to Creditor on account of its secured claim when all claims arepaid. Thus, the auction will provideCreditor with the value of its secured claim. If $\$ X$ is less than $\$ 100$, the deficiency $\$ 100-\$ X$ will become an unsecured claim, which is paid like any other unsecured claim. If Creditor wins the auction of the note with a bid $\$$, then Creditor will become the holder of the nonrecourse loan and will be regarded as having received $\$ B$ for it. Theremainder, if any, $\$ 100-\$ B$, will be an unsecured claim.

We wish to emphasize that the auction is intended to value the secured creditor's secured claim at the time of the auction, which takes place shortly before the end of the bankruptcy proceeding. As we noted earlier, secured creditors are often hurt by delays in the bankruptcy proceeding. Delays tend to erode secured creditors' entitlements because secured creditors do not al ways receive interest on their loans during the course of the bankruptcy proceeding. In addition, there may bea decline in the value of a secured creditor's collateral that the creditor is not properly compensated for, which in turn might reduce the size of its secured claim by the end of the proceeding. 105

However, our mechanism is not intended to address the problems arising from the length of the proceeding. It would not put creditors in the position they would be in if the bankruptcy proceeding were concluded quickly. Doing so would require either substantially reducing the substantial delays that currently arise in bankruptcy proceedings by, for example, adopting one of the market-based bankruptcy reforms or developing a method for compensating secured creditors for these delays.

Rather, our mechanism is intended to address the problems that arise from difficulties in valuing the collateral at the end of the proceeding, when the bankruptcy pie is to be distributed according to participants' entitlements at that time. Our mechanism would thus put creditors in the position that they would be in if collateral could be easily and accurately valued at the end of the proceeding.

105 To besure, thevalue of thecollateral may bejust as likely to increase. But the value of the secured creditor's claim is capped at theamount of the debt. As a result, delay exposes a secured creditor to moredownsiderisk than potential upsidegain. 


\section{Bidding by the Secured Creditor}

It might be argued that allowing the secured creditor to "bid-in" without paying cash distorts the outcome of the auction because it gives the secured creditor an unfair advantage. 106 A ccording to this argument, other bidders must bid in dollars whose use in the bidding has opportunity costs. In contrast, the secured creditor who bids without dollars does not incur any opportunity cost. Thus the secured creditor might be able to win the auction even when other bidders place a higher value on the asset.

This view, we believe, is mistaken. If another party wins the auction the secured creditor receives the cash paid by the winning bidder. The secured creditor who bids in and wins the auction therefore incurs an opportunity cost by giving up the cash it would have otherwise received. Thus, the opportunity costs faced by the secured creditor and the cash bidder are exactly the same.

A nother concern that might be raised relates to the possibility of informational disparities among the participants. It has been argued that in a foreclosure auction outside of bankruptcy the secured creditor may have an informational advantage over other potential bidders. This in turn may discourage other bidders from entering in the first instance, depressing the final price.

However, the secured creditor is unlikely to have a meaningful informational advantage in the auction of the nonrecourse note. To start with, under our mechanism the secured creditor has no informational advantage over other bidders whenever the value of thecollateral exceeds the face amount of the note and even one other bidder knows this, because in such case the value of the note being auctioned is simply the face amount of the note.

Furthermore, in a foreclosure auction outside of bankruptcy the secured creditor is almost always the only "insider" because the managers and owners of the dissolving firm usually cannot afford to participate. However, in the context of a firm emerging from bankruptcy as a going concern, there are likely to be other insiders and well-informed buyers besides the secured creditor participating in the auction -including the debtor itself, and perhaps potential acquirers of the firm --

106 This claim, which we shall show to be erroneous, has been made with respect to the ability of secured creditors to bid-in in foreclosuresales outside of bankruptcy. See, e.g., Erica Crohn Minchella, Bankruptcy and The Real Estate Practitioner, 85 ILL. B.J. 612, 613 (1997). 
and these bidders are likely to know as much about the value of the collateral as the secured creditor, if not more. 107

\section{W ould any Participant H ave a Basis for Complaining?}

Thus far we have assumed that the participation of liquid and fully informed buyers ensures that the auction price reflects the value of the nonrecourse note. In such a case, each participant could rely on the "market" to establish the correct value for the nonrecourse note, and therefore the correct amount for the secured creditor's secured claim. As explained, there is reason to expect this to often be the case. Let us now relax this assumption and consider the situation in which a participant does not believe that the "market" will yield the right price for the nonrecourse note. Perhaps the participant believes that there will be an insufficient number of participants entering the auction, or that even though there are many participants all of them under-estimate the value of the nonrecourse note and thus the auction price will betoo low. Could such a participant claim that the auction will yield a price for the nonrecourse note that results in the participant getting less that its entitlement?

An important advantage of our proposed mechanism is that none of the participants in the bankruptcy proceeding would haveany basis for complaining about the value of the secured claim that is generated by the auction of the nonrecourse note. In particular, no secured or unsecured creditor would be able to complain that this determination results in the participant getting less than the participant's entitlement. 108 Below we first consider whether any participant could complain that the auction

107 It is also worth noting that one of the effects of the bankruptcy proceeding is to generateinformation about thevalue of thefirm's assets that would generally not be available if the firm's assets were liquidated piecemeal outsideof bankruptcy. Thus even if the secured creditor werethe only insider participating in theauction of the nonrecourse note, theinformation generated by the proceeding may well substantially erode the secured creditor's informational advantageover outsiders.

108 The determination of the value of the secured claim should not affect the position of equityholders. Under the principle of absolutepriority, equityholders receive any valuethat remains if both secured and unsecured creditorsarepaid in full. See 11 U.S.C. $\S 1129(b)(2)$. Theauction price does not determine the extent to which creditors as a group are paid, but rather how the bankruptcy pieis divided among secured and unsecured creditors when there is not enough value to pay all of the creditors in full. 
price is too high and then examine the possibility of complaints that the price is too low. 109

\section{a. Complaining that the price is too high}

Suppose a buyer pays for the nonrecourse note an amount that is too high in the eyes of a participant. In this case, the participant cannot complain because the participant will not be getting less, and indeed will even begetting more, than what the participant believes is its entitlement.

This outcome is easy to see if the participant is the secured creditor. The higher the auction price, the more the secured creditor will get for its secured claim, and the more it will recover. Thus, if the secured creditor thinks the auction price is too high it will think it is getting more than it deserves.

Nor can an unsecured creditor complain that the price is too high. A larger secured claim for the secured creditor means, by definition, a smaller unsecured claim for the secured creditor. A smaller unsecured claim for the secured creditor, in turn, enables unsecured creditors to capture a greater fraction of the value that is available to pay unsecured claims. Thus, an unsecured creditor who believes that the auction priceis too high cannot complain that it is getting less than it deserves for its claim.

In short, a higher auction price makes both the secured creditor and unsecured creditors better off. The intuition is that when the buyer pays a higher price, it increases the size of the pie that is shared among them. 110

\section{b. Complaining that the price is too low}

Supposethat a participant believes that the auction priceis too low. At first glance, it might appear that a participant who believes the priceis

109 If the participant wereal so the buyer of the note, it would not havea good basis for complaining that the auction price is either too high or too low. The participant-buyer could not reasonably complain that the price was too high, because if it truly believed that the pricewas too high it would not have purchased the note at that price. And the participant-buyer would not complain that theprice is too low, because it benefits by purchasing the note at the lowest possibleprice We will therefore assume in the analysis that follows that the participant is a secured or unsecured creditor who is not also the buyer of the note.

110 The increase in thesize of piecomes at theexpense of thebuyer. However, the buyer cannot complain about themechanism sincenobody isforcing it to bid for the note. 
too low could complain that it is under-compensated as a result. If the participant is the secured creditor, the claim would be that the participant's secured claim is being undervalued and therefore that the participant will be paid too little for that portion of its claim; although a smaller secured claim would mean a larger unsecured claim for the secured creditor, the unsecured claim, unlike the secured claim, would not be paid in full. Thus, a secured creditor who believes its secured claim is being undervalued would complain that it is getting less than it is entitled to.

On the other hand, if the participant is an unsecured creditor, the claim would be that because the value of the nonrecourse note is too low, the amount of the secured creditor's secured claim is too small and, therefore, the amount of the secured creditor's unsecured claim is too large. A larger unsecured claim for the secured creditor means more competition for the assets available to pay the pool of unsecured claims, and therefore a lower payout rate for unsecured claims. Thus, if the participant is an unsecured creditor, it would also believe that as a result of the low auction price it is getting too little for its claim. Essentially, if the nonrecourse note is purchased at a price below what the participant believes to be the actual value, the buyer would appear to be getting a "bargain" at the expense of the total pie availablefor division among the participants in the bankruptcy. And a smaller total pie makes all those who share this pie worse off.

However, it would be inconsistent for any participant-- whether it is the secured creditor or an unsecured creditor-- to complain in this way. The auction would be open to everyone. If the participant believes that the price is too low, the participant can enter the auction, bid a slightly higher price, and make a profit equal to the difference between the auction price and the foreclosure value of the collateral, up to the amount owed. Thus, as long as a participant has sufficient liquidity to make a bid slightly higher than the winning bid, the participant has no basis for complaining that the price resulting from the auction was too low. In short, if the participant really believes the price is too low it should have put its money where its mouth is.

\section{c. Liquidity Constraints}

We still must consider the possibility that participants might have liquidity constraints and that such liquidity-constrained participants might sometimes have a basis for complaining that the price is too low. Such constraints, it would be argued, prevent a participant who fears the auction is going to result in too low a price from engaging in self-help by 
bidding. The problem of liquidity-constrained participants cannot be dismissed completely. As we will see, however, there are reasons to believe that the magnitude of this problem is likely to be very limited.

First, note that the problem of liquidity constraints does not apply to the secured creditor. As was discussed, our mechanism permits the secured creditor to bid for the nonrecourse note associated with its claim without cash. Since requiring the secured creditor to bid in cash would create a situation in which the secured creditor pays the cash back to itself, the creditor is allowed to participate simply by specifying the amount of its bid. Accordingly, a secured creditor would never be ableto complain that the auction generated too low a price for the nonrecourse note.

Let us now turn to unsecured creditors. Liquidity constraints could pose a problem for these creditors. Because an unsecured creditor must bid with cash, liquidity constraints might prevent the unsecured creditor from bidding even when the creditor believes that the auction price would otherwise be too low.

However, there is reason to believe that the problem of liquidityconstrained unsecured creditors will not be a serious one. To begin, it is important to emphasize that many unsecured creditors will not face liquidity constraints. As noted earlier, there will be many unsecured creditors in bankruptcy -- banks, finance companies, suppliers, and others -- that have enough of their own funds to bid on the note. These unsecured creditors obviously cannot complain that the price is too low.

And, unsecured creditors that do not have enough of their own funds to bid are unlikely to have difficulty borrowing the funds needed to bid for the short period of time between the auction of the note, which takes place at the end of the bankruptcy proceeding, and theresolution of the nonrecourse note, which occurs immediately after the end of the proceeding. The loan could even be secured by the nonrecourse note (and, indirectly, by the asset that secures the note).111 Consider a nonrecoursenotethat the "market" values at $\$ 80$ but which the unsecured creditor believes to beworth $\$ 100$. The unsecured creditor should be able to borrow $\$ 80$ using the note as collateral. Becauseno other bidder will be willing to bid over $\$ 80$, the unsecured creditor should be able to purchase the note using only the borrowed funds.

To besure, one cannot be certain that unsecured creditors who lack enough of their own funds to bid will always beable to borrow funds. If

111 Because the asset that is indirectly the subject of the auction served as collateral for the secured creditor's loan, it is likely to be the kind of asset that is acceptable as collateral for a loan to a bidder at the auction of the note. 
one were still concerned that the problem of liquidity-constrained unsecured creditors could be a serious impediment to the proposed mechanism, which we are not, then one might be reassured by the fact that the debtor itself, through its managers acting as "debtor-in possession" ("DIP") or thetrustee, is freeto participatein theauction. The managers, whether they are attempting to pursue the interests of old equityholders, unsecured creditors or the new owners, are likely to have an interest in increasing the value of the debtor. The same is true for the trustee in the rare cases in which a trustee is managing a debtor that will emerge as a going-concern. ${ }^{112}$ By purchasing the nonrecourse note for a price that is less than the value of the nonrecourse note -- that is, the amount the noteholder will be able to obtain from the debtor postbankruptcy -- the managers or trustee would increase the value of the debtor.113 As a result, the managers or trustee would, if permitted, have an incentive to enter the auction whenever they believe that they could buy the note for a price that is lower than its post-bankruptcy value.

The debtor purchasing the note for a price lower than its postbankruptcy value would, in turn, inure to the benefit of unsecured creditors. For example, if the debtor is to be sold as a going concern for cash, the debtor's purchase of the note at a low price should increase the price the acquirer is willing to pay for the debtor and, therefore, the pool of funds available to pay unsecured claims. Thus, the debtor - whose

112 The trusteehas a duty to maximizethevalue of the estateand the payout for unsecured claims. SeeCommodity Futures Trading Comm'n v. Weintraub, 471U.S. 343, 352-53 (1985); WARREN, supra note 12, at 26. Purchasing thenonrecoursenoteat a low price would increase the value of the estate by paying off a post-bankruptcy debt for less than the cost of extinguishing the debt after bankruptcy. This purchase would in turn makemoremoney availablefor unsecured creditors. Thus it would beconsistent with thetrustee's duties to enter theauction if thetrustee bel ieved that it could buy the note at a lower price than the foreclosurevalue of the asset (up to the amount owed).

113 Earlier we noted that one of the indirect costs of bankruptcy is that the incentives of the debtor's managers may not be well aligned with value maximization. Onemight wonder why, if managers' incentives might bedistorted, they should be permitted to bid on the nonrecourse note. Theanswer is that the bidding does not affect the ultimate disposition of theasset serving as collateral, but rather only theidentity of the person holding thenonrecoursenote. Thedisposition of the collateral is determined after theend of the bankruptcy proceeding, when the debtor is solvent. At that point, the managers will havean incentive to keep the unencumbered asset if and only if the debtor values the asset more than other parties and to sell it otherwise. This is thesameincentivemanagers would haveif the nonrecourse notew erenot purchased by the debtor but rather by a third party. See infra Part III.E.1. 
interests are aligned with those of the unsecured creditors - in effect will act as an agent for these creditors. The debtor's participation in the auction should further reduce the likelihood that any participant will complain that it is getting less than its entitlement because the auction price is too low.

\section{Second Stage: Completion of the Bankruptcy Proceeding}

The auction of the nonrecourse note would take place, as we noted, shortly before the division of bankruptcy value and the end of the proceeding. For purposes of describing the operation of our mechanism, weassume in this initial exposition that, at the end of the proceeding, the firm is sold for cash as a going concern (subject to any nonrecourse debt). Thus, once the auction of the nonrecourse note has broken the secured creditor's claim into its secured and unsecured components, the bankruptcy proceeding could conclude with the selling of the firm. The firm would be sold for an amount equal to the going concern value of its assets, less the value of the nonrecourse debt. The price would be discounted by the value of the nonrecourse debt because the buyer, through the debtor firm that it will soon own, will be required to satisfy this debt right after the bankruptcy proceeding. The cash raised from the sale of the firm as a going concern would be distributed to pay unsecured claims (including the unsecured claim, if any, of the secured creditor), and, as explained earlier, the proceeds from the auction would be used to satisfy the secured claim.

Now one might argue that a potential acquirer of the debtor firm may be reluctant to make an offer to buy the firm at the end of the proceeding without knowing exactly how much it is going to cost to buy off the noteholder after the end of the proceeding. As a result, the prices offered for the firm may betoo low, reducing the amount availableto pay unsecured claims. However, there are a number of reasons to believe that the prospect of resolving the nonrecourse debt will not disrupt bidding for the firm.

First, the potential acquirer may prefer to give up many of the assets rather than retain the assets by paying the noteholders in cash. With respect to those assets there is no need for the potential acquirer to estimate the cost of paying off the nonrecourse debt: the cost is simply the assets themselves.

Second, the potential acquirer can al ways buy off the noteholder by paying it theamount of thenonrecoursenote. Thus the potential acquirer can easily determine the maximum cost to it of keeping all of the assets serving as collateral and bid for the company as a whole accordingly. 
Third, the potential acquirer could negotiate conditional purchase agreements with key noteholders before bidding for the company as a whole. Under such an agreement, potential firm acquirer A would contract with noteholder $\mathrm{N}$ to buy $\mathrm{N}$ 's note for a price $\$ \mathrm{P}$ if and only if $\mathrm{A}$ wins the bidding for the firm. $\mathrm{N}$ could enter into similar agreements with other bidders if it wished. Bidders with such agreements would thus know the precise cost of paying off the nonrecourse debt and retaining the collateral. Noteholders may be willing to enter into such arrangements to the extent they wish to reduce ex post uncertainty and bargaining costs. In a situation in which there is a serious concern that bids would otherwise be impeded, noteholders would have a strong incentive to enter into such arrangements. Otherwise, the firm might be liquidated piecemeal and the noteholders would receiveless from thesale of the collateral than they could get from someone contemplating purchasing the firm as a going concern. 114

Finally, it is worth noting that outside of bankruptcy acquirers frequently purchasefirms that haveat l east some of their assets serving as collateral for secured debt. While the presence of such debt reduces the price a buyer would be willing to pay for a firm, it does not generally deter the buyer from acquiring it.

\section{E. Third Stage: Post-Bankruptcy Resolution of the $\mathrm{N}$ on recourse $\mathrm{N}$ ote}

The third stage in the mechanism is the resolution of the nonrecourse note after bankruptcy. We first describe the various ways in which the note could be resolved and then consider the possibility that the postbankruptcy firm may be liquidity-constrained. As we will see, once the firm emerges from bankruptcy and functions properly, the nonrecourse note can be expected to be resolved in a way that provides the noteholder with the foreclosure value of theasset (up to the faceamount of the note). The note can also be expected to be resolved without the loss of any going concern value - that is, the resolution should leavetheasset with the firm if and only if the firm is the highest valuing user of the asset.

114 Our mechanism does not require that the sale of the firm be delayed until after the auction of thenonrecoursenote. The firm could besold as a wholesubject to a nonrecourse note, with theholder of the noteto be determined at a subsequent auction of thenote. If the sale of the firm as a whole were to precede the auction of the nonrecourse note(s), the buyer of the firm could easily avoid bargaining with nonrecourse notehol ders by buying the nonrecourse notes at the auction. Thus if one were still concerned that the prospect of bargaining with noteholders would unduly depress bids for the fi rmasa wholeor scareaway all potential bidders, one could reverse the order of the auctions. 


\section{Resolution of the $\mathrm{N}$ ote}

Under our mechanism, the nonrecourse note sold at the auction would become due shortly after the debtor emerged from the bankruptcy proceeding. At that time, as is the case with any nonrecourse note that becomes due, the person who holds the note would have the right to demand payment of the face amount of the nonrecourse note (which, as was explained, corresponds to the amount owed the original secured creditor). If the debtor does not pay that amount, the holder of the note would have the right to satisfy its claim only with the collateral - that is, to have the collateral sold at auction and keep the proceeds (the foreclosure value) up to the amount owed. Returning to our example, after the bankruptcy proceeding, Debtor would have to pay the noteholder $\$ 100$. If Debtor does not pay $\$ 100$, and if Debtor and the noteholder do not reach some other accommodation, the noteholder would have the right to seize the machine, sell it at an auction, and take the proceeds up to $\$ 100$ (the face amount of the note).

As explained in Part II.A., the automatic stay generally stops creditors from seizing the debtor's assets during the bankruptcy proceeding. In the absence of the stay, a liquidity-constrained insolvent debtor would not be able to prevent creditors from seizing its assets, including those whose going concern value would be destroyed when they are taken from the debtor. The automatic stay thus preserves the going concern value, if any, of the debtor's assets.

However, at the end of the proceeding, after the debtor has been financially reorganized, the debtor should be generally solvent. This would be the case not only when the debtor is sold to a buyer for cash, as we are currently assuming to be the case, but also when the bankruptcy pie is divided through Chapter 11 bargaining or options.115 Consequently, after the end of the proceeding, an efficient resolution of the nonrecourse note -- that is, one which ensures that the debtor keeps the collateral if and only if the collateral is morevaluableto debtor than to other parties -- would not be impeded by the insolvency of the debtor.

To be sure, whether the asset will remain with the debtor, and how much the note will provide the noteholder, will depend in each case on the value placed on the asset by the debtor and by other parties. In every situation, however, the debtor will retain the collateral if and only if the collateral has going concern value for the debtor, and the noteholder will

115 In Chapter 11, one of the requirements for plan confirmation is that the plan be feasi ble-- meaning that the post-bankruptcy business must befinancially viable See 11 U.S.C. § 1129 (a)(11) (1994). 
receive the foreclosure value of the collateral, up to the amount of the note. We consider first situations in which the collateral has going concern value for the debtor and then turn to situations in which this is not the case.

\section{a. Collateral $\mathrm{H}$ as Going Concern V alue for D ebtor}

When the debtor is the highest valuing user of the collateral, it would be the highest bidder at an auction of the asset. Thus, the foreclosure value when the debtor is the highest valuing user is simply the amount that the debtor would be required to pay to win the auction. To win the auction the debtor would need to bid only slightly more than the highest bid made by other (lower-valuing) bidders. As a result, when the debtor is the highest-valuing user the foreclosure value is approximately the value of the asset to the next highest-valuing party.

The manner in which the nonrecourse note is resolved depends on the relationship between this foreclosure value and the amount of the note. Suppose that foreclosure value -- which here is what the debtor would have to pay for the collateral at auction -- isless than the amount of the note. Under these circumstances the debtor will refuse to pay the nonrecourse note in full. Instead, the debtor will pay, and the nonrecourse noteholder will agree to accept, what the noteholder would expect to get from the debtor if it took the asset and sold it at an auction. The noteholder will thus receive foreclosure value, which (in this case) is less than the amount of the note.

If the foreclosure value exceeds the amount of the note, the debtor will pay the note in full and keep the collateral. There would be no bargaining between the debtor firm and the noteholder because the firm does not need the noteholder's consent for this outcome to occur. As a result, the resolution of the note would be swift and immediate. The noteholder will get the face amount of the note, which (in this case) is less than the foreclosure value of the asset.

\section{b. Collateral D oes $\mathrm{N}$ ot $\mathrm{H}$ ave $\mathrm{G}$ oing Concern $\mathrm{V}$ alue for $\mathrm{D}$ ebtor}

When the debtor is not the highest valuing user, then the forecl osure value of the asset is the amount that the highest valuing user would need to pay to win the auction. Since the debtor will be willing to bid up to the value it places on the asset, the highest valuing user will need to bid an even higher amount. Thus when the debtor is not the highest valuing user the forecl osure value will exceed the value placed by the debtor on the asset. 
If the foreclosure value exceeds the amount owed, the debtor will pay the noteholder the face amount of the note, keep the asset, and then auction the asset off itself, so that it can capture the excess of the foreclosure value over the amount owed. Thus, the debtor will get rid of the asset and the noteholder will receive the face amount of the note, which is less than the foreclosure value.

If the foreclosure value is less than the amount of the note, the debtor will surrender the asset to the noteholder in satisfaction of the nonrecourse note, and the noteholder will then sell the asset at an auction and receive foreclosure value. Thus, in either case in which the debtor is not the highest valuing user, the noteholder will get the lesser of the foreclosure value of the collateral and the amount owed, and the debtor will give up or sell the asset.

\section{Post-Bankruptcy Liquidity Problems}

We will now consider the possibility that the post-bankruptcy debtor firm might be cash-constrained and therefore unableto redeem the collateral for cash even when it values the collateral more than other parties. This scenario is less likely to arise when, as we have assumed for purposes of this illustration, the debtor firm is sold as a going concern to a buyer for cash. Any buyer that has sufficient cash to purchase all of the firm's assets would have sufficient cash to buy the firm subject to the nonrecourse notes and then pay off the nonrecourse notes. Nevertheless, one might be concerned that liquidity problems could arise under the other two methods of division -- Chapter 11 bargaining and the options approach -- which will be discussed shortly in section F.

However, even under those two methods of division, postbankruptcy liquidity is unlikely to be a problem. Although the noteholder has a right to be paid in cash for the note, the payment to the noteholder need not be in cash. If the noteholder agrees, the debtor could "pay" the note with equity, an unsecured note, or a new secured note (recourse or nonrecourse). Thus, if the debtor prefers not to use cash to pay off the nonrecourse note, it can offer one of these non-cash alternatives. And if therisk-adjusted value of thenon-cash offer is at least as high as the foreclosure value (up to the amount of the note), which is what the noteholder would get from seizing the asset and selling it at an auction, it would be in the interest of the noteholder to accept such noncash consideration.

Under Chapter 11, the debtor may keep assets that had served as collateral for pre-bankruptcy loans over the objection of secured 
creditors. ${ }^{116}$ The noteholder's ability under our mechanism to repossess the collateral if the amount owed is not paid may therefore seem to be a departure from Chapter 11 . However, under the existing Chapter 11 rules, the debtor can keep the collateral only if the debtor pays the creditor in full for its secured claim with either cash or a note, secured by the collateral, whose payments have a present value equal to the amount of the secured claim. ${ }^{117}$ Our mechanism implements essentially the same rule: immediately after bankruptcy, a debtor wishing to retain the collateral is required to give the holder of the nonrecourse note cash or, if the noteholder agrees, non-cash consideration of equal value. For its secured claim, theoriginal secured creditor gets either cash beforetheend of the proceeding or, if it wins theauction, cash or non-cash consideration of equal value after the end of the proceeding.

An important difference between our mechanism and the treatment of secured claims in Chapter 11 is that in Chapter 11 the secured creditor could be forced to accept a note that the court decides has a value equal to theamount of the creditor's secured claim even when it in fact does not.118 Under our mechanism, which gives the noteholder the right to demand cash or the asset, the court cannot force the secured creditor to accept anything less than the amount of its secured claim. Thus our approach does better than Chapter 11 in providing secured creditors with their entitlements under current bankruptcy law. ${ }^{119}$

\section{F. Incorporating the M echanism into Bargaining-Based or O ptions-Based Bankruptcy}

Until now we have considered our mechanism in the context of a sale of the debtor firm as a going concern. We now examine how our proposal would operate in the contexts of the other two basic approaches to valuing the debtor as a whole: bargaining and options.

Before proceeding, it is important to emphasize that the first stage of the mechanism -- the auction of the nonrecourse loan -- and the third and last stage of the mechanism -- the post-bankruptcy resolution of the

116 See 11 U.S.C. § 1129(b). Seealso 11U.S.C. § 1124 (allowing debtor to reinstate loan over the objection of lender).

11711 U.S.C. § 1129(b)(2)(A)(i).

118 See JACKSON, supra note 13, at 46-47.

119 For criticisms of Chapter 11's failureto givefull priority to secured creditors, see JACKSON, supra note 13, at 211-13. In Section H, we show that the procedure could also be easily used to implement a rule of partial priority if it were decided that a secured creditor should not beentitled to thefull value of its collateral, up to the amount of its claim. 
nonrecourse loan -- would be identical under all three approaches. The only relevant difference among the three approaches lies in the second stage -- the division of the total bankruptcy pie. We thus focus on how the mechanism would implement the second stage under the bargaining and options approaches.

\section{Bargaining-Based Bankruptcy}

The bargaining approach is currently used in the United States, where it is implemented through Chapter 11.120 Thus to show how the proposed mechanism could be combined with the bargaining-based approach, we will discuss the implementation of our mechanism in the context of Chapter 11.

As when the auction of the nonrecourse note takes place in the context of a sale for cash of the debtor as a going concern, the auction of the nonrecourse note in a Chapter 11 reorganization would divide the secured creditor's claim into secured and unsecured parts. The auction price would first determine the amount of the creditor's secured claim. The secured claim would then besubtracted from theamount owed to the creditor to yield the unsecured claim (if any).

That part of a secured creditor's claim that constitutes a (fully) secured claim would be paid in full, upon completion of the bankruptcy proceeding, with the proceeds of the auction of the nonrecourse note conducted prior the end of the proceeding. Giving the auction proceeds to the secured creditor would be considered payment in full of the creditor's secured claim and thus satisfy the fair and equitable standard.

The unsecured claim of the secured creditor, if any, would be treated the same as any other unsecured claim in Chapter 11 . It would be placed in a class with other unsecured claims, be voted in favor of or against on the plan of reorganization, and, if the plan is confirmed, share pro rata in whatever consideration is received by its class.121

As explained in Part II.D.2, currently in Chapter 11 each secured claim is put in its own class and votes for or against the reorganization plan. For a plan to beconfirmed, each secured claim must therefore either be voted in favor of the plan or paid an amount that is considered to satisfy the fair and equitable standard. Thus, under current rules, there must be bargaining -- and perhaps litigation-- with each secured creditor.

120 See TABB, supra note 67, at 757-770.

121 In a Chapter 11 reorganization, the plan may sometimes havemorethan one class for unsecured claims, with each class receiving a different amount or typeof consideration. See generally EPSTEIN et. al., supra note 6, at 764-67. 
If our mechanism were adopted, however, there would be no need to bargain or litigate over the amount of each secured claim. Each secured claim would beconsidered paid in full with the proceeds of the auction of the nonrecourse note corresponding to that claim. The addition of our proposal to a Chapter 11 regime would therefore considerably reduce the number of classes whose approval would be needed for plan confirmation, and thereby substantially facilitate bargaining in, and the resolution of, Chapter 11 cases. 122

\section{Options-Based Bankruptcy}

As explained in Part II.E.2, the options approach, one of the two market-based alternatives to Chapter 11 for dividing the value of the bankruptcy pie, involves allocating options on the debtor's value to the participants in the bankruptcy proceeding. The division of value results from the participants' own decisions to exercise the options they receive. The options are designed in such a way that nobody can complain that they have ended up with less than what they are entitled to.

As noted, however, to implement the options approach it is necessary to rank order all of the participants' claims. This ranking, in turn, requires breaking secured creditors' claims into secured and unsecured parts. Our mechanism would use the auction of the nonrecourse note to break apart such claims.

The auction would take place just prior to the distribution of the options. The result of the auction would provide the information necessary to implement the options approach, that is, the ranking and amount of claims. The secured claim would be paid in full with the proceeds of the auction. If the secured creditor has an unsecured claim, that creditor would also receive an option of the type received by holders of unsecured claims. The participants would know that the firm emerging from Chapter 11 would have the nonrecourse note outstanding

122 If it is unknown whether the plan will be confirmed at the time of the auction -- that is, if it is unknown whether the bankruptcy proceeding iscoming to an end and the nonrecourseloan can be shortly resolved outsi de of bankruptcy then the auction price would be lower to reflect the possibility of delay. This discount would in turn tend to undermine the auction's effectiveness as a mechanism for determining the amount of the secured claim. Under these conditions, the bid could bemadeconditional on the plan being confirmed within a short period of time and payable at the end of the proceeding. This should eliminate the discount that would otherwise arise from the possibility that resolution would be delayed. 
against it. They would exercise their options in accordance with their own estimates of the firm's value, taking into account this liability.

\section{G. An A Iternative Version of the M echanism}

Our approach is based on the insight that the amount of a secured creditor's secured claim is equival ent to the value of a nonrecoursenotein the amount of the creditor's claim, backed by the secured creditor's collateral. The problem of determining the amount of the secured claim (and the amount of the unsecured claim) therefore translates into the problem of valuing such a nonrecourse note. Wehavesuggested that that the valuation of the nonrecourse note be effected through an auction of the note shortly before the end of the bankruptcy proceeding. And we have shown that this method of valuing secured claims could be used under any of the three basic approaches to allocating the value of the bankruptcy pie - the sale of the debtor for cash (auctions), bargaining, and options.

In this section we put forward an alternative version of the mechanism that could be used whenever the debtor firm as a whole is to be sold for cash. This version is also based on recognition of the equivalence between the amount of a secured creditor's secured claim and the value of a corresponding nonrecourse note. Under this alternative version, however, there would be no auction of the note. Instead, the secured creditor would simply keep the note and then capture the value of the noteitself after bankruptcy.

After the completion of the bankruptcy proceeding, the secured creditor would hold the nonrecourse note. If the debtor buys the note, whether for its face value or a lower amount, the purchase price would determine the amount of the creditor's secured claim and the payment to the creditor would be considered payment of that claim in full. If the secured creditor repossesses and sells the collateral at auction, the sale price again would determine the amount of the secured claim and the money received by the creditor would be considered payment in full of the secured claim. The resolution of the note would also determine the amount of the secured creditor's unsecured claim.123 As under the auction version of the mechanism, the secured creditor would get the foreclosure value of the collateral, up to the amount owed, and the asset

123 In order for theamount of the unsecured claim to beestablished, thesecured creditor would be required to pay in cash (rather than with another noteor equity) if it purchases the nonrecourse note. 
would remain with the debtor if and only if the debtor is the highest valuing user.

The advantage of this alternative version is that there would be no auction. Although the transaction costs and delay associated with the auction of the nonrecourse note are likely to be minimal, under the alternative version there would be no costs or delay during the proceeding whatsoever.124

However, under the non-auction version, the secured creditor's unsecured claim can be determined only after the resolution of the note, which occurs after the end of the bankruptcy proceeding. In contrast, under the auction version the unsecured claim is determined before the end of the bankruptcy proceeding, and therefore can be treated like any other unsecured claim that is known before the end of the proceeding. Thus, under the non-auction version, there must be a means to ensure that the secured creditor's unsecured claim is treated like similar claims. Below, we offer two methods that could be used to ensure that, under the non-auction version of the mechanism, the secured creditor's unsecured claim is treated in the same way as all other general unsecured claims.

One way for dealing with the secured creditor's unsecured claim would be to delay distribution of the proceeds of the sale of the debtor until after the post-bankruptcy resolution of the nonrecoursenote. Recall that when the auction version of our mechanism is used in the context of a sale of the firm as a whole for cash, in the second stage the firm is sold to the highest bidder and the proceeds of the auction of the firm and the proceeds of the earlier auction of the note are distributed together. The bankruptcy proceeding is then brought to a close. The third and last stage of the mechanism is the resolution of thenonrecourse note after theend of the bankruptcy proceeding.

Under the non-auction version, in the second stage the firm would also be auctioned for cash and emerge as a solvent entity, bringing the bankruptcy proceeding to an end. However, the proceeds of the sale of the firm would be kept in escrow until the amount of the secured creditor's unsecured claim is established by the post-bankruptcy resolution of the nonrecourse note. At that time the unsecured claim whose amount is determined by the resolution of the nonrecourse note would be pooled with other unsecured claims and paid pro rata like any

124 Thealternativeversion might beappealing to those who arew orried that at auction thesecured creditor might buy thenonrecoursenotefor less than its actual value, which in turn would give it too large an unsecured claim. Thealternative version might also be appealing to those concerned about the problem of asymmetric potentials for gain or loss depressing the price of the note, seesupra Part III.C.1, which could arise under the auction-based procedure. 
other unsecured claim. This approach would involve moving one element that was originally in stage two -- distribution of the proceeds of the sale of the firm -- to the third stage. Delaying the distribution of cash until after the end of the bankruptcy proceeding is unlikely to give rise to any significant administrative costs.

Consider the following example. Suppose that Debtor's value as a going concern is $\$ 200$. Unsecured creditors are owed $\$ 150$. In addition, Creditor has lent Debtor $\$ 100$, secured by a machine with a foreclosure value of $\$ 50$. A bsent the machine, Debtor's value as a going concern is $\$ 140$. In other words, the machine is worth $\$ 60$ to the Debtor - morethan to any other party. Creditor's secured claim is converted into a nonrecourse note, with a face amount of $\$ 100$, backed by the machine worth $\$ 50$. Debtor is then sold for cash, subject to the nonrecourse note, and emerges as a solvent entity. The cash is set aside in an escrow account pending resolution of the nonrecourse note, which will indicate the amount of Creditor's unsecured claim. After the resolution of the note, the person managing the escrow account makes a pro rata distribution of the proceeds of the sale of the firm to all of those holding unsecured claims, including Creditor.

In this example, at the time of the sale of Debtor for cash, the prospective owners of Debtor anticipate that they will pay Creditor $\$ 50$ in satisfaction of the nonrecourse note (to avoid surrendering the machine, which is worth $\$ 60$ the Debtor). Thus, Debtor, which has a going concern value of $\$ 200$, will be sold subject to a liability of $\$ 50$. As a result, the purchase price will be $\$ 150$ ( $\$ 200-\$ 50)$. The $\$ 150$ is put in an escrow account. Subsequently, Debtor pays Creditor $\$ 50$ for Creditor's nonrecourse note, and Creditor submits an unsecured claim of $\$ 50$ to the person managing the escrow account. There are thus a total of $\$ 200$ in unsecured claims (Creditor's $\$ 50$ plus another $\$ 150$ ) that must be paid with the $\$ 150$ in the escrow account available to pay unsecured claims. Each claim is accordingly paid 75 cents on the dollar.

An al ternative method for dealing with unsecured claims is to have the post-bankruptcy debtor, after thenonrecoursenoteis resolved and the amount of the unsecured claim is determined, pay thesecured creditor for its unsecured claim whatever it would have received had its unsecured claim been pooled with other unsecured claims. ${ }^{125}$ So, for example, if the unsecured claim is determined to be $\$ 150$ and the payout rate for

125 Cf. Frederick Tung, Taking Future Claims Seriously: Future Claims and Successor Liability in Bankruptcy, 49 CASE WESTERN RESERVE L. REV. 435, 500 (1999) (suggesting a post-bankruptcy treatment of unmatured tort claims based on the payout rate for unsecured claims at the end of the bankruptcy proceeding). 
unsecured claims at the end of the proceeding was $50 \%$, the debtor would, after resolving the nonrecourse note, be required to pay the secured creditor $\$ 75$.

Under the auction version, the debtor will emerge from bankruptcy subject to one or more nonrecourse notes. Thus parties who are contemplating buying the debtor (under theauction approach), accepting securities in the debtor (under Chapter 11), or considering whether to exercise their options in the firm (under the options approach) must take into account the liability represented by these nonrecourse notes in deciding their course of action. Under thenon-auction version, the debtor will emerge from bankruptcy with the same nonrecourse liabilities. In addition, when the second method of disposing of the unsecured claim is used the debtor will emerge with liabilities in connection with the secured creditor's residual unsecured claims.

However, a bidder could easily determine the liabilities represented by these unpaid unsecured claims. The amount of each unsecured claim is simply the amount owed the creditor, less the value of the nonrecourse note, which the bidder would need to estimate in any event. The payout ratethat will be applied to unsecured claims at the end of the proceeding will depend on the total amount of unsecured claims presented by unsecured creditors, which is easily observable, and the amount of value available for distribution at the end of the proceeding, which is simply the amount bid by the winner of the auction.

This second method for dealing with unsecured claims of secured creditors -- delaying the distribution of the proceeds from the sale of the debtor until after the end of the proceeding and requiring the debtor to pay the unsecured claim in part -- would yield the same correct result as the first method. Consider the outcome it would produce in the example used above. Suppose that in this example Debtor is sold for cash, subject to the nonrecourse note and the requirement that the Debtor pay Creditor's unsecured claim at the samerate as other unsecured claims are paid in the proceeding. Bidders will bewilling to pay $(\$ 200-\$ 50-X(\$ 50))$ for Debtor, where $X$ is the fraction of unsecured claims that are paid at the end of proceeding. However, $\mathrm{X}$ is simply the amount that bidders pay for Debtor, divided by the total amount of unsecured claims (other than that of Creditor). Thus

$$
X=\frac{\$ 200-\$ 50-X(\$ 50)}{\$ 150} \text { or } X=3 / 4 \text {. }
$$

Because $X=3 / 4$, the buyer will pay $\$ 112.50$ for Debtor. This $\$ 112.50$ will bedistributed to pay the unsecured creditors, who will get 75 cents on the 
dollar. Thenew owners of Debtor will then pay Creditor $\$ 50$ for the nonrecourse note, be presented by Creditor with an unsecured claim for $\$ 50$, and pay on account of that claim $\$ 37.50$.

\section{H. U sing the M echanism to Implement Partial Priority}

A s explained in Part II.A.2.b, it has been a fundamental princi ple of bankruptcy law that a secured creditor has a right to receivethefull value of its collateral, up to the amount owed. The implementation of this principle -- which in prior work we have called the principle of "full priority" 126 -- requires thevaluation of collateral. Currently this valuation is effected through litigation and bargaining. We have shown that our proposal could implement full priority -- in a way that is quicker, less costly, and more consistent with participants' entitlements, than is possible with the current approach.

However, as we have argued elsewhere, full priority might not be optimal from an efficiency perspective. 127 In particular, full priority may lead to distortions in arrangements between borrowers and their creditors, including the excessive use of security interests and insufficient monitoring of borrowers by secured creditors. We have therefore suggested that according only partial priority to secured claims might be efficient. We have also demonstrated that partial priority would be consistent with principles of fairness and respect for the creditor's bargain. ${ }^{128}$ In this section we will show that the mechanism we put forward could also be used to implement rules that give only partial priority to secured claims.

Partial priority rules can usefully be divided into two categories. The first is "carveout rules," rules under which a certain fraction of a creditor's collateral is set asidefor unsecured creditors before determining the amount of the creditor's secured claim. The other category, which we will call "claim-conversion rules," consists of rules that determine the secured claim in the same manner as under full priority, but then convert a portion of the secured claim into an unsecured claim. Below we show

126 See Bebchuk \& Fried, U neasy Case, supra note 18, at ; Bebchuk \& Fried, Reply to Critics, supra note 18 .....; Fried, supra note 18, at

127 See Bebchuk \& Fried, U neasy Case, supra note 18, at Reply to Critics, supra note, 18 , at ; Fried, supra note 18 , at Bebchuk \& Fried,

128 See Bebchuk \& Fried, U neasy Case, su pra note 18, at 931-32; Bebchuk \& Fried, Reply to Critics, supra note 18 , at $1290-91$. 
that our mechanism could be used to implement, without resorting to bargaining or litigation, either a carve out or a claim-conversion rule.129

First consider carveout rules. Under a carveout, a specified fraction of the secured creditor's collateral is set aside for unsecured creditors. An example of this approach is the twenty percent Article 9 carve out proposed by Elizabeth Warren.130 Under Warren's proposal, up to twenty percent of a borrower's personal property serving as collateral for Article 9 security interests would beset aside to pay unsecured claims.

Such a carve out rule could beimplemented by modifying thethird stage of the mechanism -- resolution of the nonrecourse note after the bankruptcy proceeding. In particular, thenonrecoursenotewould not, as when the mechanism is implementing full priority, give the noteholder the right to seize the collateral, sell it at an auction, and keep the proceeds up to the amount owed. Instead, if the post-bankruptcy debtor does not pay the amount owed, the noteholder would have the right to seize the collateral, sell it at an auction, and keep a specified fraction of the proceeds, up to the amount owed. The remainder of the proceeds would be returned to the debtor.

For example, under a twenty percent carve out rule, eighty percent of the proceeds at the auction would begiven to the noteholder, up to the amount owed. Under such a rule, the noteholder would expect to get eighty percent of the foreclosure value of the asset, up to the amount owed. Therefore the auction price -- which would be the amount the secured creditor receives for its secured claim -- should be eighty percent of the foreclosure value of the asset, up to the amount owed -- which would be the secured creditor's entitlement under a twenty percent collateral carve-out rule. The remainder, if any, would be an unsecured claim.

Let us now turn to claim-conversion rules. Under such a rule, a secured creditor's secured claim and unsecured claim would first be determined in the samemanner as under full priority, and then a portion

129 We will use the auction-based mechanism (rather than the alternative, auction-less version of the mechanism) to illustratehow partial priority would be implemented. However, it would bestraightforward to show that theal ternative version can also implement partial priority.

130 Elizabeth Warren, An Article 9 Set-A side for Unsecured Creditors, 51 CONSUMER FIN. L. Q. REP. 323, 323 (1997). Warren's proposed set-asidewould be applied under both state law (outside bankruptcy) and in bankruptcy. Our procedure could be used to implement the set-aside in bankruptcy. For a comparison of Warren's proposal to partial priority rules that apply to all collateral, but only in bankruptcy, see Bebchuk \& Fried, Reply to C ritics, supra note18, at 134748. 
of that secured claim would be converted to an unsecured claim and added to the creditor's original unsecured claim. Thus, unlike in the case of a carve-out rule, the secured creditor will not be paid in full unless all creditors are paid in full. An example of this is the seventy-five percent fixed fraction rule we put forward for consideration in earlier work.131 Under this rule, a secured creditor would be paid in full for seventy five percent of its (full priority) secured claim; the remainder of the secured claim would be added to the creditor's unsecured claim.

A claim-conversion rule could be implemented by modifying the second stage of our mechanism -- the division of value at the end of the bankruptcy proceeding. The nonrecourse note would givethe noteholder the same rights as under the full priority mechanism. Thus, the noteholder would expect to get one hundred percent of the foreclosure value of the collateral, up to the amount owed. However, the amount of the secured claim -- as determined by the auction of the note-- would be reduced by the amount specified under the partial priority rule. For example, the seventy-five percent fixed-fraction rule we put forward132 would pay the secured creditor in full for seventy-five percent of its secured claim, with the other twenty-five percent of the secured claim becoming unsecured.

\section{CONCLUSION}

One of the more perplexing and seemingly insoluble problems in business bankruptcy is the problem of valuing assets serving as collateral when the debtor's assets have going concern value. Valuing collateral in such cases is essential because the value of the asset determines the amount of the secured creditor's secured claim and therefore the payment received by the secured creditor at the end of the proceeding. Currently, assets in such cases are valued by a court after litigation, or through bargaining among the parties. These methods give riseto deviations from parties' bankruptcy entitlements, and they add costs, delay, and uncertainty to the bankruptcy proceeding. The problem of valuing collateral arises not only under current rules, but would also arise under the two market-based al ternatives to Chapter 11 -- auctions and options.

This paper has proposed a new approach to valuing collateral that can address the problem under both Chapter 11 as well as under the two alternative, market-based regimes. The approach is based on reconceptualizing the amount of a secured creditor's secured claim as the

131 Bebchuk \& Fried, U neasy Case, supra note 18 , at $909-11$.

132 Id. at 909. 
value of a certain nonrecourse note. The part of the secured creditor's claim (if any) that is unsecured can then simply be thought of as the amount owed less the value of the nonrecourse note. This reconceptualization has enabled us to put forward a mechanism for dividing the secured creditor's claim into its secured component and its unsecured residual. The mechanism involves converting the secured claim into a nonrecourse note that could be asserted against the debtor immediately after the bankruptcy proceeding. The value of the note would be determined by the price the note fetches at an auction of the note that is held shortly before the end of the proceeding. We have also put forward an alternative mechanism for determining the value of the note that can be used whenever the firm is sold for cash at the end of the bankruptcy proceeding. Under this alternative mechanism, the nonrecourse note is given to the secured creditor in satisfaction of its secured claim and its value is determined by the post-bankruptcy resolution of the note.

Wehaveshown that themechanism, appropriately designed, could provide outcomes consistent with participants' entitlements, with no participant having any basis to complain that the secured creditor is overor under-compensated. In addition, the mechanism would cause neither disruption nor loss of value during or after the bankruptcy proceeding. We have also shown that the mechanism could be used not only in Chapter 11 but also in combination with the two market-based approaches that have been put forward as alternatives to Chapter 11 . Finally, we have explained how our mechanism could be used to implement various kinds of partial priority rules if it were decided to give secured creditors less than full priority in their collateral. We hope that this new approach to valuing secured claims will in fact contribute to improving the design of bankruptcy procedures. 